\title{
ENVIRONMENTAL COMPARISON OF INDOOR FLOOR COVERINGS
}

Teresa Ros-Dosdá1 ${ }^{12 *}$; Irina Celades ${ }^{1}$; Laura Vilalta'; Pere Fullana-i-Palmer ${ }^{2}$; Eliseo Monfort ${ }^{3}$

1 Instituto de Tecnología Cerámica (ITC). Asociación de Investigación de las Industrias Cerámicas (AICE). Universidad Jaume I; Avda. Sos Baynat s/n, 12006, Castellón, Spain.

${ }^{2}$ UNESCO Chair in Life Cycle and Climate Change (ESCI-UPF). Passeig Pujades 1, 08003 Barcelona, Spain.

${ }^{3}$ Universidad Jaume I; Avda. Sos Baynat s/n, 12006, Castellón, Spain.

*Corresponding author: teresa.ros@itc.uji.es; phone: +34 9643424 24; fax: +34 964342425 


\title{
Graphical abstract
}

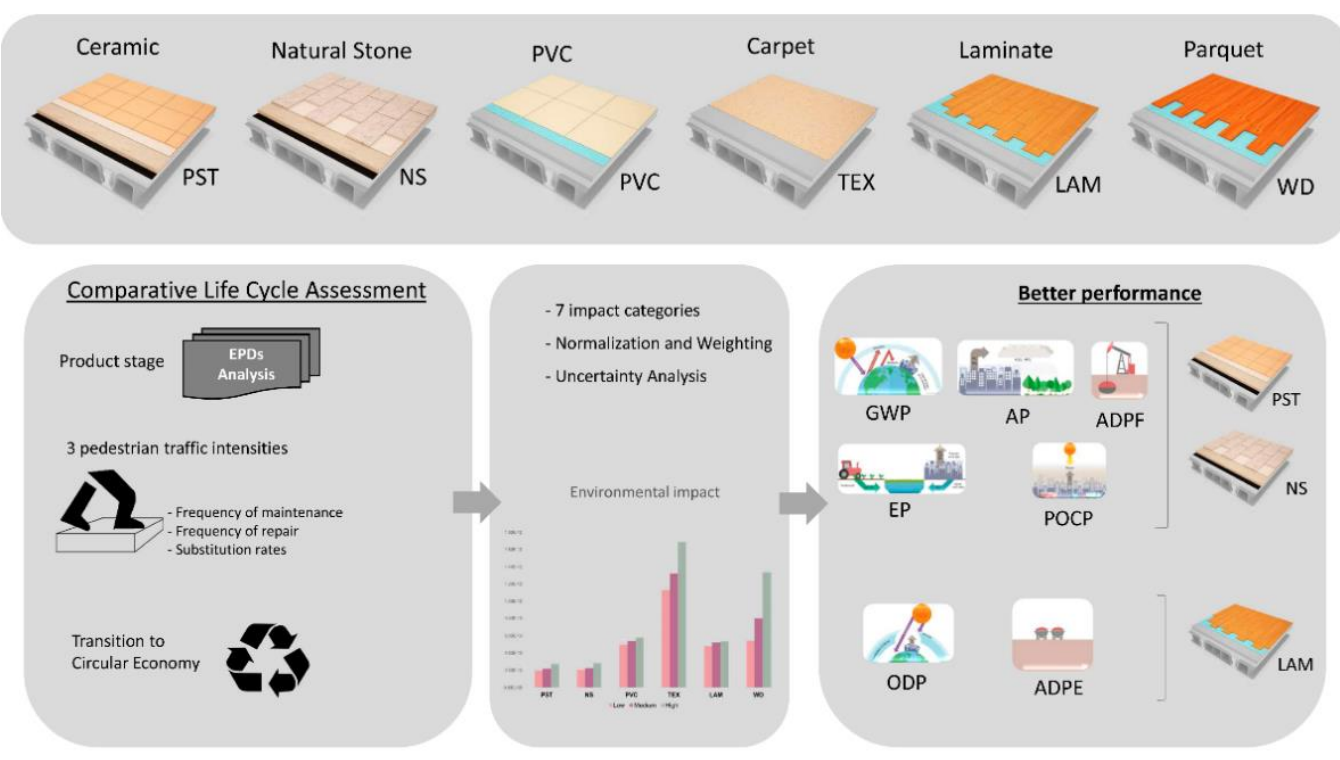

\begin{abstract}
Appropriate selection of construction materials plays a major role in a building's sustainable profile. The study sets out a comparative life cycle assessment of indoor flooring systems of different nature. The flooring systems consisted of coverings and, where required, bonding material and/or impact soundproofing material. The following coverings were assessed: inorganic (natural stone and ceramic tiles), polymer (carpeting and PVC), and wood-based (laminate and parquet) coverings. The life cycle assessment scope was defined cradle to cradle, i.e. product stage, transport to the construction site, installation of all construction elements, use, and valorisation by recycling, as end-of-life transition scenario towards a circular economy. In the use stage, three scenarios were defined as a function of pedestrian traffic intensity, which determined maintenance, repair, and replacement operations and frequencies. The environmental impacts of the coverings product stage were taken from previously assessed and selected Environmental Product Declarations (EPDs), as these are standardised public documents devised to provide environmental life cycle information. The method adopted in the study suggests that, though the use of EPDs as information source is interesting, erroneous conclusions may be drawn if the EPDs are not comparable and/or if the comparison is not made in the building context. The results indicate that the flooring systems with inorganic coverings performed best in the global warming, acidification, eutrophication, photochemical ozone creation, and abiotic depletion for fossil resources impact categories, whereas laminates performed best in the abiotic depletion for non-fossil resources and ozone layer depletion impact categories. The carpet flooring system performed worst in every impact category except photochemical ozone creation potential.
\end{abstract}

\section{Key words:}

Floor Systems; Life Cycle Assessment; Environmental Product Declaration 


\section{Highlights}

- Six indoor flooring systems were compared through Life Cycle Assessment, considering three pedestrian traffic intensity scenarios in the use stage.

- 149 EPDs were analysed as starting point in the comparative study.

- The importance of considering the whole life cycle vs. just the product stage was evidenced on comparing different alternative construction solutions.

- Cradle-to-cradle scope was considered, based on a transition to the circular economy.

- Floor systems with inorganic coverings (natural stone and ceramics) performed best in most' of the environmental impact categories studied.

\section{List of abbreviations}

ADPE: abiotic depletion potential for non-fossil resources

ADPF: abiotic depletion potential for fossil resources

AP: acidification potential

EP: eutrophication potential

EPD: environmental product declaration

FU: functional unit

GWP: global warming potential (100 years)

LAM: laminate

LCA: life cycle assessment

MSL: material service life

NS: natural stone

ODP: ozone layer depletion potential (steady state)

PA: polyamide

POCP: photochemical ozone creation potential

PST: ceramic tile, mainly porcelain stoneware tile

PVC: polyvinyl chloride

RSP: reference study period

TEX: synthetic carpet

VOC: volatile organic compound

WD: multilayer and solid parquet

\section{Introduction}

The construction sector is a major materials consumer. In fact, the European Union deems it a key sector in the attainment of the objectives in the Roadmap to a Resource Efficient Europe 
(RERM) (COM/2011/0571 final, 2011) and the EU Action Plan for the Circular Economy (COM/2015/0614 final, 2015), as about $50 \%$ of materials extraction, $30 \%$ of water consumption, and $30 \%$ of waste generation are associated with this sector (COM/2014/445 final, 2014). In addition, buildings account for most of the total final energy consumption in the EU (42\%) (COM/2007/0860 final), the use stage being the most noteworthy regarding energy consumption (Cuéllar-Franca and Azapagic, 2012). A literature review carried out by Iribarren et al., 2015, confirmed the enormous efforts being made to reduce the impacts of this stage, albeit often at the expense of using energy-intensive materials, thus counterbalancing energy consumption. In this sense, Asif et al., 2007, identified cement, wood, and ceramic tiles as the three major energy expensive materials. Consequently, appropriate selection of construction materials plays a major role in a building's environmental profile (Akadiri, 2015; COM/2014/445 final, 2014; Häfliger et al., 2017; Zabalza et al., 2011).

Life Cycle Assessment ( $\mathrm{LCA}$ ) is unquestionably the most widely used methodology for evaluating product environmental impacts, particularly those of construction products (Basbagill et al., 2013; Iribarren et al., 2015; Zabalza Bribián et al., 2009). LCA applications in this sector include sustainability assessments of materials (Balaguera et al., 2018), construction systems (Albertí et al., 2019), building designs (Assiego de Larriva et al., 2014; Häfliger et al., 2017; Khasreen et al., 2009; Zabalza Bribián et al., 2009); as well as of cities (Albertí et al., 2017); innovation and ecodesign (Chang et al., 2014; Fazeni et al., 2014; Ortiz et al., 2009; Puig et al., 2017); and marketing, for example, through Environmental Product Declarations (EPDs) (Gazulla Santos, 2012).

In the particular case of floor covering materials, the application of LCA has consistently drawn attention in the literature (Abeysundara et al., 2009; Almeida et al., 2016a; Benveniste et al., 2011; Bovea et al., 2010; Gazi et al., 2012; Günther and Langowski, 1997; Ibáñez-Forés et al., 2011; Islam et al., 2015; Jönsson et al., 1997; Jönsson, 1999; Minne and Crittenden, 2015; Nebel et al., 2006; Nicoletti et al., 2002; Paulsen, 1999; Pini et al., 2014; Potting and Blok, 1995; Reza et al., 2011; Ros-Dosdá et al., 2018a, 2018b; Tikul and Srichandr, 2010; Traverso et al., 2010). Appendix 1 presents a synoptic analysis of these literature references based on the coverings, applied methods and impacts considered, as well as on the scope and boundaries of the system and functional or declared unit. Analysis of this information allows important differences to be noted, which prevent direct comparison of the results for conclusions to be drawn. Generally speaking, certain coincidences were identified, in which it was concluded that linoleum was the most interesting flooring, followed by vinyl, from an environmental viewpoint, when soft and/or resilient floorings were compared (Jönsson et al., 1997; Minne and Crittenden, 2015; Potting and Blok, 1995). However, hardly any comparative studies were found on hard floor coverings (Nicoletti et al., 2002) and no individual or comparative LCA studies were found that included laminate floorings. Finally, it may be noted that none of these studies addressed the integration of the coverings into the construction system as a whole, and only a minority considered the use stage.

On the other hand, drawing up LCAs for EPDs has mainly been driven by the increasing demand for sustainable construction certificates (Anand and Amor, 2017; Ganassali et al., 2018; Gelowitz and McArthur, 2016; Monfort, 2012) and by approval of the construction materials regulation (Regulation (EU) No 305/ 2011, 2011), which insists on using EPDs where available, for sustainability assessment in the efficient use of construction resources and impacts. In fact, EPDs are a basic and very valuable resource in the early stages of building design (Anand and Amor, 2017; Passer et al., 2015), as these are often the only information architects and planners have to compare and decide on different construction and/or component options (Bovea et al., 2014; IBU-EPD programme). 
However, certain precautions need to be taken into account in performing comparative analyses. Such use requires understanding EPDs contents, limitations, and the underpinning PCRs to be able to interpret EPDs properly (Gazulla Santos, 2012) and draw accurate conclusions. In the case of comparisons, these must be made considering the functionality and environmental performance either on a whole building level or on lower levels, for example for construction systems, assembled systems, components or products (construction solutions), assuring a series of principles that ensure objectivity and transparency (EN 15804+A1, 2013).

Thanks to the publication of the Basic Product Category Rules for Construction Products (EN 15804+A1, 2013), the European EPDs for floor coverings are relatively homogeneous with regard to the stages that must be declared (A1-A3). However, in subsequent stages, inconsistencies are to be found among EPDs of the same category with different and even with the same PCRs. This is because these stages contain more assumptions and, at present, PCRs do not always establish reference scenarios to avoid inconsistencies among EPDs of the same program (e.g. default values in waste management, bonding materials, and maintenance operations), besides the differences in the verification process of the different programs (Gelowitz and McArthur, 2017; Hunsager et al., 2014; Minkov et al., 2015). For example, the PCRs for ceramic coverings in the GlobalEPD (GlobalEPD, 2018) and IBU-EDP (Institut Bauen und Umwelt e.V., 2017a) programs are very detailed in these stages, whereas the PCRs for carpeting in IBU-EPD (Institut Bauen und Umwelt e.V., 2017b) allow the declarer greater freedom.

This study sets out a comparative analysis of six floor coverings, together with the respective construction system that contains each. The study was conducted on six materials deemed most representative of those used as indoor floor coverings (Table 1).

The industry and business stakeholders request information to compare construction products to make decisions and also to know the positioning of their products against the competitors, from an environmental point of view. Considering that there are no current publications that: i) include the most common types of coverings in Spain and Europe; ii) the existing publications on environmental impacts of the life cycle of coverings do not allow comparison among them; and iii) there is a lack of studies that are supported by objective, complete and available information for companies and industry (i.e. EPDs), the present work is proposed.

Table 1 Production in 2016 of the studied floor coverings.

\begin{tabular}{|c|c|c|c|}
\hline \multicolumn{4}{|c|}{ Production (million m²) } \\
\hline Covering & World & Europe & $\mathbf{U S}^{(6)}$ \\
\hline Ceramic tile ${ }^{(1)}$ & 13056.0 & 1304.0 & 321 \\
\hline Textile floor covering ${ }^{(2)}$ & 12095.0 & 848.0 & 1150 \\
\hline Natural Stone ${ }^{(3)}$ & 514.3 & 87.4 & 33.5 \\
\hline Laminate $^{(4)}$ & 477.0 & 371.0 & 104 \\
\hline Parquet ${ }^{(5)}$ & n.a. & 80.4 & 163 \\
\hline PVC & n.a. & n.a. & 447 \\
\hline \multicolumn{4}{|l|}{ n.a. Not available } \\
\hline \multicolumn{4}{|c|}{$\begin{array}{l}\text { World and European data: Baraldi, 2017; European Carpet and Rug Association (ECRA), 2018; Carlo Montani, 2018; } \\
\text { European Producers of Laminate Flooring (EPLF), 2018; European Federation of the Parquet Industry (FEP), } 2017 \\
\text { US data: Floor covering weekly, } 2018\end{array}$} \\
\hline
\end{tabular}


In this context, the main purpose of this study was to perform a comparative LCA study of flooring systems with a cradle-to-cradle scope, using the information contained in the relevant EPDs (as these are public documents issued by the industry, which are verified and updated $(<5$ years)) to assess the product stage (A1-A3), modelling the other life cycle stages in the same building context in terms of three scenarios in the use stage (maintenance, repair, and replacement operations) as a function of different pedestrian traffic intensities, and applying a progressive transition towards a circular economy, both in the use stage and in the end-of-life stage.

\section{Method}

\subsection{Objective and scope}

The study sought to quantify the environmental impact of six major flooring systems (FSs) installed indoors throughout their life cycles, starting out from the information contained in their EPDs.

To do so, an LCA was performed of each FS with a cradle-to-cradle scope, also known as an end-of-life recycling approach (or avoided burden approach) (Frischknecht, 2010; Häfliger et al., 2017; Silvestre et al., 2014), modelled within a building use context under the same system boundaries, scenarios, scope, and considerations for each transport, installation, use and endof-life stage, in order to allow subsequent comparison, observing the requirements set in standard ISO 14025, 2006, Section 6.7.2.

The LCAs were carried out in accordance with the international standards (ISO 14040, 2006; ISO $14044,2006)$ and the core construction PCRs (EN 15804+A1, 2013). The standards on sustainability of construction works (EN 15978, 2011) were also taken into account. The LCA software GaBi 8 (Thinkstep AG, 2018a) and related databases (Thinkstep AG, 2018b), as well as carefully selected EPDs of coverings, were used in the environmental assessment.

A Reference Study Period (RSP) of 50 years was used. The Functional Unit was defined as the quantity of construction elements required to build $1 \mathrm{~m} 2$ of indoor flooring system in Spain intended to last for 50 years. The study considered the useful life of the coatings and the number of installations needed to cover the RSL, rounded up to the next integer value, as shown in Table 2.

\subsection{Life cycle inventory analysis}

\subsubsection{Studied flooring system compositions}

Types of materials and their arrangement in construction systems vary according to types of buildings and countries (IEE Project TABULA, 2012; Ortiz et al., 2009). To define the FSs for this study, the construction solutions that contained them were first defined, using the following Spanish documents and regulations as references: Código Técnico de la Edificación (the Technical Building Code) (Ministerio de Fomento de España, 2011); Catálogo de Elementos constructivos (Catalogue of Construction Elements) (IETcc-CSIC, 2011); and Documento Básico de protección frente al ruido (Basic Document on Protection against Noise) (Ministerio de Fomento de España, 2009). The studied construction system of horizontal partitions was a Floating floor screed of cement mortar, as the authors deemed this to be the most generic alternative described in these documents. The system involved a floor made up of a layer of about 5-cm-thick cement mortar installed on a sheet of impact sound insulation material, the 
screed being covered with a finish. A schematic illustration of this type of floor is shown in Fig. 1.

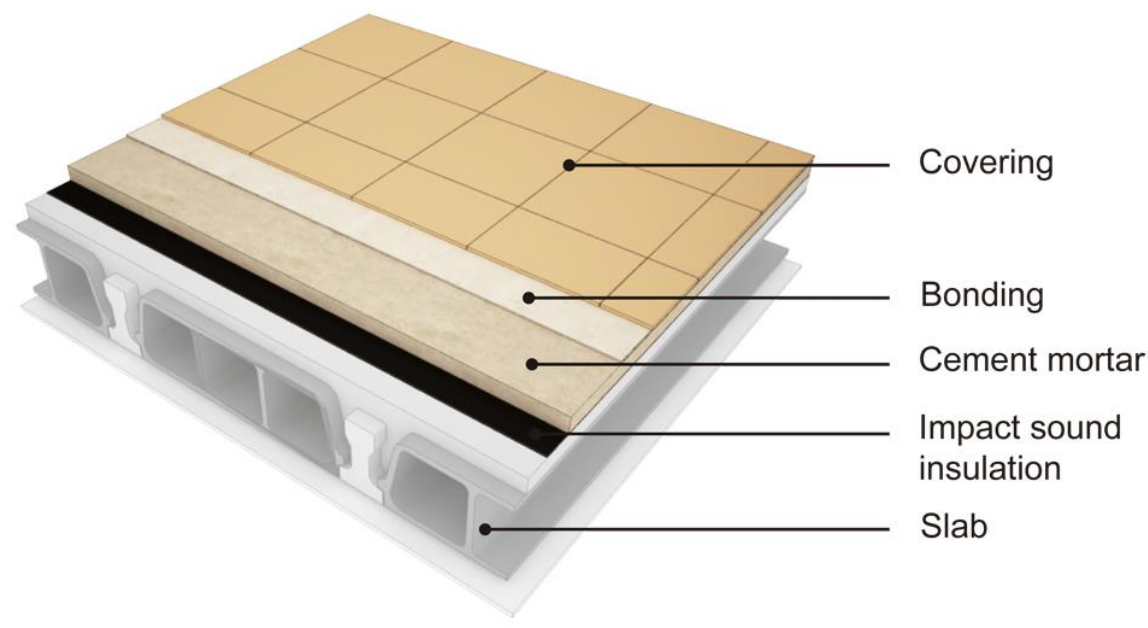

Fig. 1 Horizontal partition systems (Source: own figure from IETcc-CSIC, 2011)

Fig.1 illustrates the five layers making up a construction solution of this type, namely covering, bonding material, cement mortar screed, impact sound insulation, and slab. In this comparative study, the common components in the construction solutions, i.e. the cementitious mortar and slab, were excluded. In this study, the remaining system is designated the flooring system (FS).

The studied FSs are detailed in Table 2. The coverings properties regarding product mass, thickness, varieties and Material Service Life (MSL) were obtained from the selected EPDs (appendix 2); the arrangement and mass of the materials in the different intermediate layers were drawn from CYPE Ingenieros, 2018, databases. To facilitate discussion of the results, the coverings were divided into three groups, based on their nature: inorganic (ceramic tiles and natural stone), polymer (carpeting and PVC), and wood-based (parquet and laminate) coverings. 


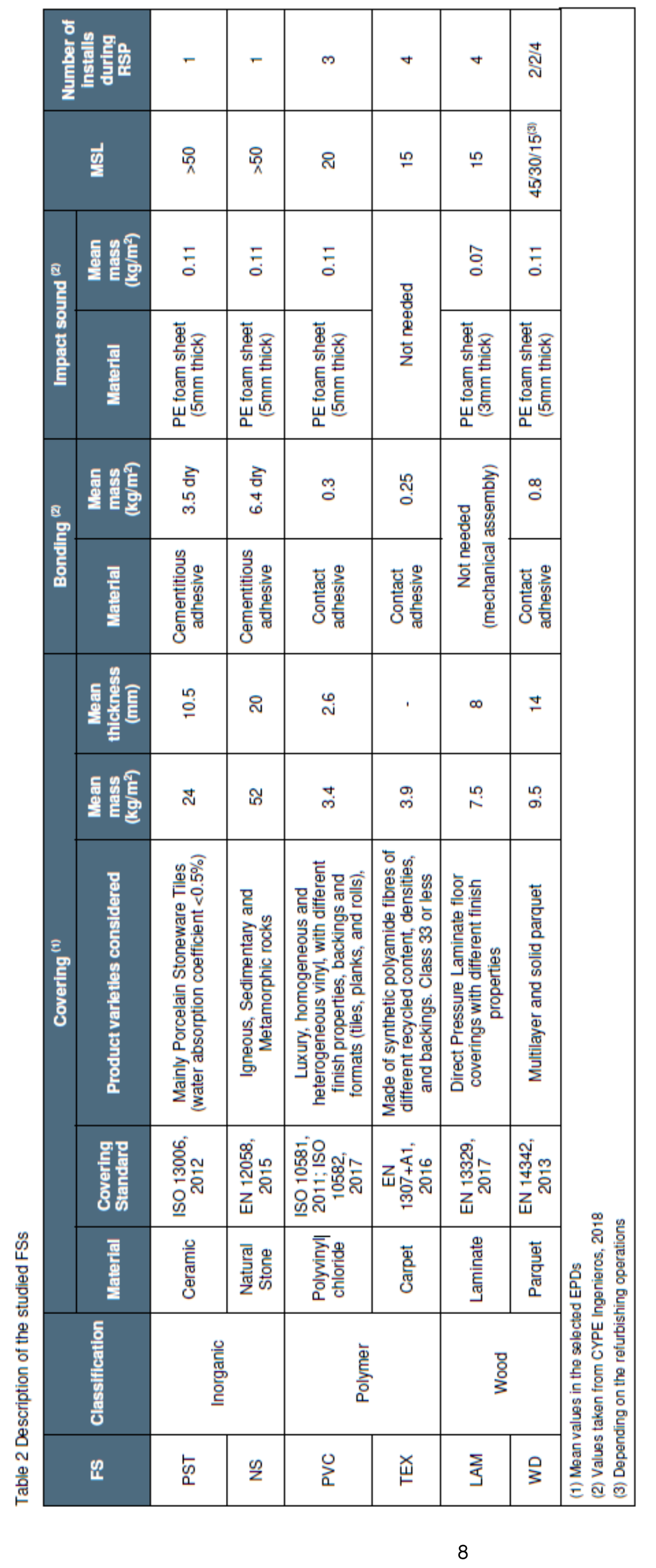




\subsubsection{Description of the FSs life cycles}

The environmental information on the FSs life cycles was organised in terms of the following stages: product, distribution, construction, use (differentiating maintenance, repair, and replacement operations), and end-of-life management.

The product stage included raw materials extraction, transport and manufacturing.

The distribution stage covered transport from the manufacturing plants to the construction site. These distances have been calculated from each EPD's company site to Madrid (Spain), obtaining a weighted average value by the number of EPDs of each type of covering (see Figure A2.1. in Appendix 2). The distances considered and means of transport applied are those shown in Table 3.

Table 3 Distance and means of transport applied in the distribution stage

\begin{tabular}{|c|c|c|c|c|c|c|}
\hline Means of transport & PST & PVC & LAM & TEX & NS & WD \\
\hline Truck & $595 \mathrm{~km}$ & $5357 \mathrm{~km}$ & $2170 \mathrm{~km}$ & $2414 \mathrm{~km}$ & $3000 \mathrm{~km}$ & $1216 \mathrm{~km}$ \\
\hline Cargo & $180 \mathrm{~km}$ & $714 \mathrm{~km}$ & $180 \mathrm{~km}$ & $184 \mathrm{~km}$ & $0 \mathrm{~km}$ & $2500 \mathrm{~km}$ \\
\hline
\end{tabular}

The construction stage included the following operations: manufacture and transport (average distance: $100 \mathrm{~km}$ ) of the bonding materials and impact-proof soundproofing sheets, where needed; managing of packaging and construction waste, $5 \%$ loss being assumed; and manual installation of each FSs element in the building. The impact caused by unloading and movement of the material at the construction site was excluded. As to waste managing, recycling of $70 \%$ and landfilling of the rest (Eurostat, 2019), except for laminate floorings were applied. Laminate flooring waste recycling at the moment of the study was estimated to be nil owing to the multicomponent nature of laminates, so that $100 \%$ of the laminate flooring waste was deemed to be landfilled (Parador GmbH \& Co.KG, 2013).

The FSs use stage included maintenance, repair, and replacement operations. The emissions generated during use of the coverings were excluded as, in their EPDs, most manufacturers declared that, due to known VOC-decay curves of the product, after the first year no productrelated VOC emissions were relevant, though studies are to be found that contradict this criterion (Saarela, 1999; Sollinger et al., 1993; Tuomainen et al., 2004). In comparative analysis, aspects such as comfort, visual warmth, and aesthetic versatility have been omitted owing to the subjectivity and/or difficulty involved in quantifying these, thus avoiding adding greater uncertainty to the results.

If a system lasts for a long time, values for some of the variables influencing the impact may vary and using data of the current year may consequently lead to uncertainty. The longevity of construction systems, such as flooring systems, leads to uncertainty in the use stage (Akadiri, 2015), especially because of auxiliary products and technologies involved in operations relating to this stage, such as the energy mix. To lessen this uncertainty, the evolution of the Spanish electricity mix over the next 50 years was considered, according to the predictions of Capros et al., 2013.

Moreover, certain data, such as those for cleaning, highly depend on user habits and installation site demands (Jönsson, 1999; Nebel et al., 2006). In order to cope with this fact, three use scenarios were considered, based on low, medium, and high pedestrian traffic intensity, consistently assuming certain cleaning, repair, and replacement operations and frequencies. To specify the maintenance operations (cleaning) and their frequencies as a function of these three 
scenarios, the following literature sources were consulted: EPDs that included information in this regard; Diputación de Castellón, 2018; and Minne and Crittenden, 2015.

The differences found in cleaning frequencies and intensity, which explain the different energy and cleaning product (water and detergents) consumptions, stem from the unequal cleanability of the surfaces, owing to differences in surface microstructure and properties of the materials. For example, in the case of TEX, a bed is cleaned, whereas in WD, little water is used.

The cleaning operations and pedestrian traffic intensity scenario for each floor covering are detailed in Table 4.

Table 4 FSs maintenance scenarios (cleaning operations)

\begin{tabular}{|c|c|c|c|c|c|c|c|}
\hline \multirow[b]{2}{*}{ FS } & \multirow[b]{2}{*}{$\begin{array}{c}\text { SCENARI } \\
0\end{array}$} & \multicolumn{6}{|c|}{ CLEANING ACTIVITIES } \\
\hline & & $\begin{array}{l}\text { Wet } \\
\text { mop }\end{array}$ & $\begin{array}{c}\text { Wet } \\
\text { mop+clean } \\
\text { er }\end{array}$ & $\begin{array}{l}\text { Househol } \\
\text { d } \\
\text { vacuum }\end{array}$ & $\begin{array}{l}\text { Profession } \\
\text { al cleaning } \\
\text { system - } \\
\text { Water }\end{array}$ & $\begin{array}{l}\text { Professional } \\
\text { cleaning } \\
\text { system - } \\
\text { Water+clean } \\
\text { er }\end{array}$ & $\begin{array}{l}\text { Profession } \\
\text { al vacuum }\end{array}$ \\
\hline \multirow{3}{*}{$\begin{array}{l}\mathrm{PS} \\
\mathrm{T}\end{array}$} & Low & $\begin{array}{c}1 \mathrm{x} / \text { wee } \\
\mathrm{k}\end{array}$ & $0.5 x /$ week & & & & \\
\hline & Medium & $\begin{array}{c}7 x / \text { wee } \\
k\end{array}$ & 3.5x/week & & & & \\
\hline & High & & & & $14 \mathrm{x} /$ week & $7 \mathrm{x} /$ week & \\
\hline \multirow{3}{*}{ NS } & Low & $\begin{array}{c}1 \mathrm{x} / \text { wee } \\
\mathrm{k}\end{array}$ & $0.5 x /$ week & & & & \\
\hline & Medium & $\begin{array}{c}7 x / \text { wee } \\
k\end{array}$ & $3.5 x /$ week & & & & \\
\hline & High & & & & $14 x /$ week & $7 x /$ week & \\
\hline \multirow{3}{*}{$\begin{array}{c}\text { PV } \\
\text { C }\end{array}$} & Low & & $1 \mathrm{x} /$ week & $2 x /$ week & & & \\
\hline & Medium & & $7 x /$ week & $5 x /$ week & & & \\
\hline & High & & & & & $14 x /$ week & \\
\hline \multirow{3}{*}{$\begin{array}{l}\text { TE } \\
X\end{array}$} & Low & & $1 \mathrm{x} /$ year & $3 x /$ week & & & \\
\hline & Medium & & $2 x /$ year & $7 x /$ week & & & \\
\hline & High & & & & & $4 x /$ year & 14x/week \\
\hline \multirow{3}{*}{$\begin{array}{l}\text { LA } \\
M\end{array}$} & Low & & $1 \mathrm{x} /$ week & $3 x /$ week & & & \\
\hline & Medium & & $7 x /$ week & $7 x /$ week & & & \\
\hline & High & & & & & $7 x /$ week & $14 x /$ week \\
\hline \multirow{3}{*}{ WD } & Low & $\begin{array}{c}1 \mathrm{x} / \text { mont } \\
\mathrm{h}\end{array}$ & $0.5 \mathrm{x} /$ month & $3 x /$ week & & & \\
\hline & Medium & $\begin{array}{c}2 \mathrm{x} / \mathrm{mont} \\
\mathrm{h}\end{array}$ & $1 \mathrm{x} /$ month & $7 x /$ week & & & \\
\hline & High & & & & 1x/week & 0.5x/week & 14x/week \\
\hline
\end{tabular}


The amount of water and cleaning agent, as well as the electricity consumptions of the domestic and professional equipment in each cleaning operation, together with the information sources and FSs involved, are detailed in Table 5.

Table 5 Water, detergent, and energy consumptions for each cleaning cycle

\begin{tabular}{|c|c|c|c|}
\hline $\begin{array}{c}\text { Consumable in cleaning } \\
\text { operations }\end{array}$ & FSs involved & Amount & Sources \\
\hline \multirow{2}{*}{$\begin{array}{l}\text { Water per cleaning } \\
\left(1 / \mathrm{m}^{2}\right)\end{array}$} & All except TEX & 0.1 & \multirow{4}{*}{$\begin{array}{l}\text { Mean from EPDs, Diputación de } \\
\text { Castellón, 2018; and Minne and } \\
\text { Crittenden, 2015. }\end{array}$} \\
\hline & TEX & 2.1 & \\
\hline \multirow{2}{*}{$\begin{array}{l}\text { Cleaner per cleaning } \\
\left(\mathrm{kg} / \mathrm{m}^{2}\right)\end{array}$} & All except TEX & 1.0E-04 & \\
\hline & TEX & 5.0E-02 & \\
\hline \multirow{2}{*}{$\begin{array}{l}\text { Energy in domestic } \\
\text { vacuuming } \\
\left(\mathrm{kWh} / \mathrm{m}^{2}\right)\end{array}$} & All except TEX & 2.3E-03 & $\begin{array}{l}\text { Power information provided by } 10 \\
\text { commercial models. Vacuum } \\
\text { efficiency from Minne and } \\
\text { Crittenden, } 2015 \\
\end{array}$ \\
\hline & TEX & 1.4E-02 & $\begin{array}{l}\text { Power information provided by } 10 \\
\text { commercial models. Vacuum } \\
\text { efficiency from Minne and } \\
\text { Crittenden, } 2015 \\
\end{array}$ \\
\hline \multirow{2}{*}{$\begin{array}{l}\text { Energy in professional } \\
\text { vacuuming } \\
\left(\mathrm{kWh} / \mathrm{m}^{2}\right)\end{array}$} & All except TEX & 5.4E-04 & $\begin{array}{l}\text { Power information and vacuum } \\
\text { efficiency provided by } 4 \text { commercial } \\
\text { models. }\end{array}$ \\
\hline & TEX & $6.6 \mathrm{E}-03$ & $\begin{array}{l}\text { Power information and vacuum } \\
\text { efficiency provided by } 4 \text { commercial } \\
\text { models. }\end{array}$ \\
\hline \multirow{2}{*}{$\begin{array}{l}\text { Energy in professional } \\
\text { cleaning } \\
\left(\mathrm{kWh} / \mathrm{m}^{2}\right)\end{array}$} & All except TEX & 6.3E-04 & $\begin{array}{l}\text { Power information and vacuum } \\
\text { efficiency provided by } 7 \text { commercial } \\
\text { models. }\end{array}$ \\
\hline & TEX & 1.6E-02 & $\begin{array}{l}\text { Power information and vacuum } \\
\text { efficiency provided by } 6 \text { commercial } \\
\text { models. }\end{array}$ \\
\hline
\end{tabular}

The repair operations were solely applied to natural stone and parquet. Natural stone repair consisted of polishing, buffing, and waxing; parquet repair consisted of sanding or scraping followed by varnishing. The repair operations were solely applied to natural stone and parquet. Natural stone repair consisted of polishing, buffing, and waxing; parquet repair consisted of sanding or scraping followed by varnishing. The possibility of replacing accidently broken parts was not considered in the scope of this study, as any estimation would appear to be quite subjective. Table 6 details the number of repairs during RSP service life, power and efficiency of the electrical equipment, and amount of wax or varnish for surface treatment. 
Table 6 Number of coverings repairs in 50 years

\begin{tabular}{|l|c|c|}
\hline & Natural Stone & Parquet \\
\hline Number of repairs: low/medium/high & $1 / 3 / 5$ & $5 / 10 / 15$ \\
\hline Equipment power & $2.2 \mathrm{~kW}^{(1)}$ & $1.5 \mathrm{~kW}^{(2)}$ \\
\hline Operation efficiency & $30 \mathrm{~s} / \mathrm{m}^{2(1)}$ & $30 \mathrm{~s} / \mathrm{m}^{2(1)}$ \\
\hline Wax/varnish & $0.02 \mathrm{~kg} / \mathrm{m}^{2(3)}$ & $0.33 \mathrm{~kg} / \mathrm{m}^{2(4)}$ \\
\hline (1) Nicoletti et al., 2002 & \\
(2) Information provided by Holzmann Maschinen GmbH, 2018 & \\
(3) Information provided by Fila Industria Chimica S.p.A., 2018 \\
(4) Consulted EPDs
\end{tabular}

To define the replacement operations, the number of coverings replacements required as a function of the coverings MSL during the 50-year RSP was calculated (Table 2).

The operations involved in each replacement were as follows: disassembly of the coverings and, where applicable, of the bonding material; transport of the material removed; treatment and/or disposal of this material; manufacture of replacement material; transport to the construction site; and installation.

In the end-of-life management of the replaced materials waste, a progressive transition to $100 \%$ recycling in the course of 50 years, in a phase-in to a circular economy, was applied, as detailed in Table 7.

Table 7 Scenarios in the course of 50 years' construction and demolition waste management

\begin{tabular}{|l|c|c|c|c|}
\hline \multirow{2}{*}{$\begin{array}{c}\text { Time elapsed } \\
\text { since installation }\end{array}$} & \multicolumn{2}{|c|}{ Laminates } & \multicolumn{2}{c|}{ Other coverings } \\
\cline { 2 - 5 } $\begin{array}{l}\text { 0 years (losses on } \\
\text { installation) }\end{array}$ & 0 & 100 & 70 & 30 \\
\hline $15-20$ years & 25 & 75 & 80 & 20 \\
\hline 30 years & 50 & 50 & 90 & 10 \\
\hline 40 years & 75 & 25 & 95 & 5 \\
\hline 50 years & 100 & 0 & 100 & 0 \\
\hline
\end{tabular}

The end-of-life stage considered the dismantling and demolition of all FSs elements, transport, and end-of-life management. The dismantling and demolition operations of each FSs element were assumed to be either manual or mechanised, depending on the hardness of the covering and bonding material (CYPE Ingenieros, 2018). The construction materials end-of-life stage entailed great uncertainty, as it was to take place in a distant future (Silvestre et al., 2014). In this case, applying a cradle-to-cradle approach (Häfliger et al., 2017; Silvestre et al., 2014; Wolf et al., 2010), it was assumed that within 50 years, the scenario would be $100 \%$ recycling for every type of studied covering, incineration and landfilling options being excluded. For this scenario to materialise, it will be necessary to promote changes in building design in order to facilitate dismantling of the different construction materials (Zabalza et al., 2011).

In this sense, the processes prior to the end-waste state condition for the materials exiting the system as secondary material were considered, as well as all operations beyond the system required for processing this secondary material and the benefits obtained from recycling, were included. Specifically, in this LCA comparative study, it was assumed that the impacts of these 
operations were those declared by modules C3 (waste treatment) and D (benefits and loads beyond system boundaries) (Silvestre et al., 2014) of the consulted EPDs that provided this information. The theoretical replacement ratios of the recovered inert and wood materials were 1:1, those of the polymer materials being 1:0.81 (Mercante et al., 2012).

In the particular case of the wood-based coverings (parquet and laminates), biogenic carbon was quantified by means of the $-1 /+1$ calculation method (method currently defined by the TC 350 and ISO 21930, 2017 standards), the stored amount of biogenic carbon thus being emitted in the end-of-life stage.

All transport considered in this study occurred with a $27 \mathrm{t}$ truck, which conforms to the Euro 6 standard.

\subsubsection{Data sources}

The characteristics of each element making up the FSs were drawn from CYPE Ingenieros, 2018.

The environmental information relative to the coverings product stage (A1-A3) was taken from the published EPDs (Anand and Amor, 2017; Lasvaux et al., 2014; Passer et al., 2015), while the information on the other constituents was obtained from the GaBi (Thinkstep AG, 2018b) and ELCD (Joint Research Centre, 2015) databases.

For the subsequent stages (A4-C4/D), the EPD values were not used directly, owing to the inhomogeneity of the assumptions made in drawing up the scenarios (Hill et al., 2018). To reduce uncertainty and provide comparability, common scenarios based on the descriptions supplied by the manufacturers in their EPDs and on the literature sources (appendix 1) were defined. On the other hand, the inventory data of the inputs and outputs were selected from the GaBi (Thinkstep AG, 2018b) and ELCD (Joint Research Centre, 2015) databases.

\section{EPD information processing}

To obtain representative environmental information on the product stage (A1-A3) of the different coverings, the following EPD programs were consulted: the International EPD® System; Institut Bauen und Umwelt e. V. (IBU-EPD); DAPcons; GlobalEPD; Inies and EPDnorge, carrying out the following procedure:

1) EPDs selection. The following criteria were applied: suitability of the functional characteristics of the product in the building context; conformity to standard EN 15804:2012+A1:2013; verification by a third party; current validity; exclusion of EPDs not written in English, French, German, or Spanish (the authors' mother tongue).

2) EPDs comparability assessment. The criteria set out in standards ISO 14025:2006 and EN 15804:2012+A1:2013 were applied. To simplify application of these criteria, a method similar to that used by Gelowitz and McArthur, 2017, (Table 8) was adopted.

3) Data representativeness. A unit conversion process was performed where necessary, in addition to statistical processing of the impact values. In general, the 50th percentile of the sample was taken as representative value of each covering (Häfliger et al., 2017; Hill et al., 2018).

The analysis of the consulted EPDs is set out in appendix 2. 
Table 8 Comparability assessment criteria

\begin{tabular}{|l|l|}
\hline \multicolumn{1}{|c|}{ Concept } & \multicolumn{1}{c|}{ Criterion } \\
\hline FU/DU & The Functional or Declared Unit must be the same or be convertible \\
\hline $\begin{array}{l}\text { Characterisation } \\
\text { factors }\end{array}$ & $\begin{array}{l}\text { The characterisation factors must be the same or their units must at least } \\
\text { be convertible, e.g. from ounces to } \mathrm{kg} \text { or } \mathrm{m}^{3} \text { to litres }\end{array}$ \\
\hline $\begin{array}{l}\text { Mandatory } \\
\text { content for } \\
\text { comparison } \\
\text { according to } \\
14025 / 15804\end{array}$ & $\begin{array}{l}\text { Description of the product; } \\
\text { PCR identification; } \\
\text { Listing of materials and substances to be declared; } \\
\text { The list of environmental impacts of the product stage (A1-A3) is } \\
\text { presented separately from those of the other life cycle modules }\end{array}$ \\
\hline Cut-off rules & $\begin{array}{l}\text { The cut-off rules must be identical regarding the mass, volume } \\
\text { percentage that may be excluded from the calculations }\end{array}$ \\
\hline
\end{tabular}

\subsection{Assessment of the environmental impact}

The information relative to each FS was modelled with the LCA software GaBi 8 (Thinkstep AG, 2018a), following the considerations of standards ISO 14040-44, 2006, EN 15804+A1, 2013, and EN 15978, 2011.

The studied environmental impact categories, in accordance with standard EN 15804+A1, 2013, are listed in Table 9.

Table 9 Assessed environmental impact categories

\begin{tabular}{|c|c|c|}
\hline Impact category & Acronym & Unit \\
\hline Global Warming Potential (100 years) & GWP & $\mathrm{kg} \mathrm{CO}_{2}$ Equivalent \\
\hline Acidification Potential & AP & $\mathrm{kg} \mathrm{SO}_{2}$ Equivalent \\
\hline Eutrophication Potential & EP & $\mathrm{kg} \mathrm{PO}_{4}{ }^{3-}$ Equivalent \\
\hline Ozone Layer Depletion Potential (steady state) & ODP & kg CFC-11 Equivalent \\
\hline Photochemical. Ozone Creation Potential & POCP & $\mathrm{kg} \mathrm{C}_{2} \mathrm{H}_{4}$ Equivalent \\
\hline Abiotic Depletion - elements & ADPE & $\mathrm{kg}$ Sb Equivalent \\
\hline Abiotic Depletion - fossil fuels & ADPF & MJ \\
\hline
\end{tabular}

Finally, beyond the scope of standard ISO 14040-44, 2006, owing to the subjectivity of the process, to simplify comparison of the six FSs and seven impact categories and to visualise the relative magnitude of the impacts and handle the trade-offs (Laurin et al., 2016), weighting and normalisation factors were applied (Table 10). This enabled a single dimensionless value for each FS and use scenario to be obtained. The applied weighting factors were those obtained by Thinkstep "LCIA Survey 2012, Global, CML 2016, incl. biogenic carbon (global equivalents weighted)". The applied normalisation factors were taken from "CML2001 - Jan. 2016, World, year 2000, incl. biogenic carbon (global equivalents)" (Table 10). Further information on the results for each impact category may be found in appendix 3 . 
Table 10 Weighting and normalisation factors

\begin{tabular}{|c|c|c|}
\hline Environmental indicators & Weighting Factors & Normalisation Factors \\
\hline GWP & 0.193 & $4.22 \mathrm{E}+13$ \\
\hline AP & 0.127 & $2.39 \mathrm{E}+11$ \\
\hline EP & 0.137 & $1.58 \mathrm{E}+11$ \\
\hline ODP & 0.129 & $2.27 \mathrm{E}+08$ \\
\hline POCP & 0.135 & $3.68 \mathrm{E}+10$ \\
\hline ADPE & 0.133 & $3.61 \mathrm{E}+08$ \\
\hline ADPF & 0.146 & $3.80 \mathrm{E}+14$ \\
\hline
\end{tabular}

\subsection{Uncertainty analysis}

As all environmental studies, this comparative study carries a certain degree of uncertainty. In particular, the environmental impacts associated with the coverings product stage stemmed from median data, whose original sample in some cases exhibited a very scattered distribution (appendix 2), in addition to displaying differences regarding source, input data uncertainty, etc. Moreover, assumptions with a high degree of subjectivity were defined in other life cycle stages, such as cleaning or repair operations and frequencies.

The Monte Carlo simulation was programmed, randomly distributing the median data of each life cycle stage and its standard deviation for each FS, represented by a normal distribution, performing a number of 1000 iterations.

Scenario analyses were also carried out on maintenance operations, material service life and end-of-life management of the FS.

\section{Results and discussion}

Applying the above methodology yielded Fig. 2, which exhibits the contribution of each studied FS to each environmental impact category, differentiating the FS life cycle stages and representing the three use scenarios considered as a function of low, medium, and high pedestrian traffic intensity (from left to right). The results are then discussed from the viewpoint of each impact category, first indicating the results of the comparative analysis based on a cradle-to-gate scope and then on a cradle-to-cradle scope, highlighting the most noteworthy stages in each case.

\section{Limitations}

It may be noted that the impact values of the coverings associated with the product stage (cradle to gate) stemmed from previously selected EPDs. This methodology implies some considerations to be taken into account:

- The discussion of the results associated with this life stage is, therefore, limited to the generic information on floorings in scientific publications and from the interpretation of the results included in some EPDs (13.6\% of the consulted EPDs).

- The selected EPDs are registered in different programs, they have been carried out with the support of different software and databases, the data correspond to different years and come from different geographical origins (see Appendix 2). However, all EPDs were in force at the time of conducting the study and comply with EN 15804:2012+A1:2013, 
which means that the validity of the data and the time constrains were checked during the third party verification processes demanded by the EPD programmes. Moreover, in this study, a uncertainty and quality analysis of data has been carried out to ensure that neither this procedure nor choices lead to biased conclusions in the study.

- This approach reliably reflects the method followed by non-academic users of EPDs." 


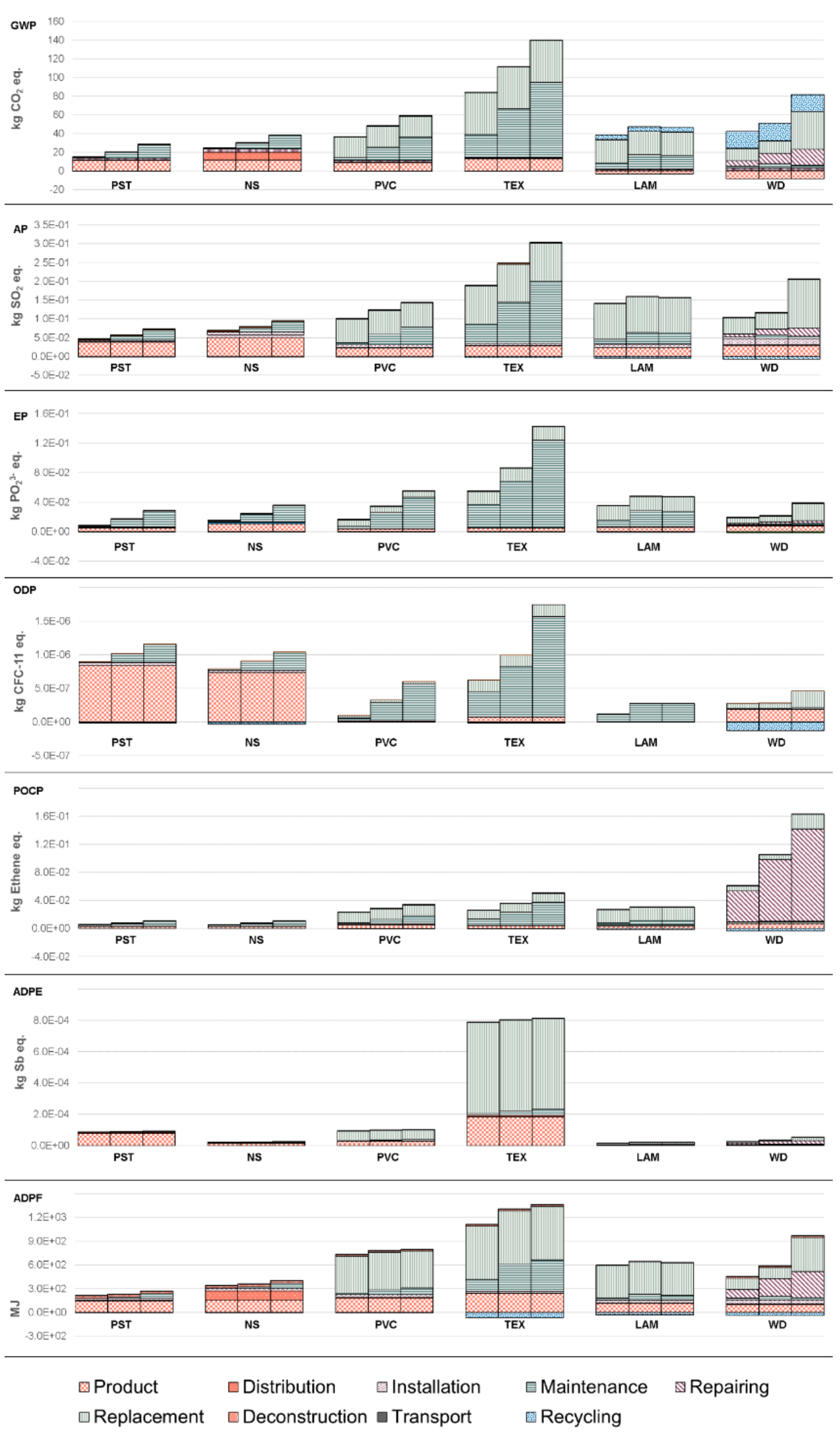

Fig. 2 Environmental impacts of the FSs studied in each defined use scenario, indicating the contribution of each life cycle stage. The values refer to the FU. For each FS, the bars represent low, medium, and high intensity pedestrian traffic, from left to right. 


\subsection{Global warming potential (GWP)}

Comparison solely of the mandatory information contained in the EPDs product stages might lead to the erroneous conclusion that the wood-based coverings performed best, as they generated positive impacts owing to the carbon sequestered by the biomass (Jungmeier et al., 2002; Nebel et al., 2006; Nebel and Cowell, 2003). However, analysis of the FSs from a life cycle perspective revealed that the FSs with inorganic coverings generated a lower environmental impact in every one of the three traffic intensity scenarios defined in the use stage. The lowest values were obtained for PST: 14.2; 16.7; and $23.2 \mathrm{~kg} \mathrm{CO} 2$ eq./FU for low, medium, and high pedestrian traffic intensity, respectively. The order of magnitude was similar to that obtained in other studies (Almeida et al., $2016\left(20.1-23.3\right.$ kg CO 2 eq. $/ \mathrm{m}^{2}$; Ibañez-Forés et al., 2011 (18 kg $\mathrm{CO}_{2}$ eq. $\left./ \mathrm{m}^{2}\right)$; Ros-Dosdá et al., 2018a (11.14-16 kg CO 2 eq. $\left.\left./ \mathrm{m}^{2}\right)\right)$. The values determined for NS were slightly higher than those for PST, in contrast to the conclusion drawn by Nicoletti et al, 2002, though in that study different MSL and another impact assessment methodology based on eco-indicators was applied. In contrast, the most unfavourable values were obtained for TEX (77.5, 99.0, and $141.1 \mathrm{~kg} \mathrm{CO}_{2}$ eq./FU) in the three studied traffic scenarios, which matched the conclusions of the study by Minne and Crittenden, 2015.

With regard to the stages that exhibited the greatest repercussion, it may be observed that, in the inorganic coverings, the product stage displayed the greatest impact in every analysed scenario, just as in other studies (Almeida et al., 2016b; Benveniste et al., 2011; Bovea et al., 2010; Ibáñez-Forés et al., 2011; Nicoletti et al., 2002; Ros-Dosdá et al., 2018a), stemming from the great energy consumption in the manufacturing stage, combined with the ease of maintenance in the use stage and the high product lifespan (CET, 2014; DAPcons, 2015; GlobalEPD, 2018; Minne and Crittenden, 2015; Thuring et al. 2013). Conversely, in LAM and PVC, the greatest impact was found in the replacement stage, the coverings being penalised by their short lifespans: 15 and 20 years, respectively. TEX, whose origins lie in polyamide manufacture, obtained the worst results in all use scenarios, owing to high energy consumption in the manufacturing and maintenance stages, together with a relatively short lifespan (15 years). WD was the second most unfavourable covering, with a significantly higher impact when installed in areas with high pedestrian traffic because, on requiring more repair operations, its service life decreased, and it needed to be replaced more frequently. The WD end-of-life stage had a significant effect ( $>25 \%$ of the life cycle), as it was in this stage in which part of stored biogenic carbon was theoretically released (Jungmeier et al., 2002). To be noted is further the impact stemming from the varnish used in the WD repair operations $(26 \%$ in an average scenario).

\subsection{Acidification potential (AP)}

In a cradle-to-gate scope, all coverings exhibited very similar impact values, those of the inorganic coverings being slightly higher. However, in a cradle-to-cradle scope, the FSs with inorganic coverings again performed best, regardless of the use stage scenario, PST performing best, with values of $0.048-0.074 \mathrm{~kg} \mathrm{SO}$ eq./FU in low and high traffic scenarios, respectively, yielding similar values to NS, whose impact was slightly greater as both its specific weight and cementitious adhesive consumption were twice as high. In contrast, TEX performed worst owing to maintenance, its impact stemming from electricity in vacuuming, use of detergent, and replacement operations. For the medium traffic scenario both stages accounted for $85 \%$ of the total life cycle. In low and medium traffic scenarios, PVC and WD yielded similar values, with differences in the WD cleaning frequencies, repair, and installation stages. In the installation stage, WD needed a greater amount of adhesive $\left(0.8 \mathrm{~kg} / \mathrm{m}^{2}\right)$ than PVC $\left(0.3 \mathrm{~kg} / \mathrm{m}^{2}\right)$ (CYPE 
Ingenieros, 2018). In high traffic scenarios, WD required additional replacement as repair sanding diminished WD thickness. In general, the cleaning operations seemed to have no determining importance, except for TEX.

\subsection{Eutrophication potential (EP)}

In a cradle-to-gate scope, the NS covering exhibited the greatest impacts, and the PVC covering the lowest. On extending the scope, the PST FSs performed best even when installed in areas with high maintenance demands, exhibiting impact values (2.85E-02 $\mathrm{kg} \mathrm{PO}_{4}{ }^{3-}$ eq./FU) similar to those calculated by Almeida et al., 2016. PST impact was mainly caused by the product stage, specifically the NOx emissions generated during raw materials extraction and transport (Bovea et al., 2007) and by natural gas combustion in the tile drying and firing stages (Bovea et al., 2010). In this impact category, TEX again performed worst due to the ammonia emissions associated with the high detergent and chemicals demand in cleaning $\left(0.06 \mathrm{~kg} / \mathrm{m}^{2}\right.$ per annum according to the EPDs), matching the conclusions drawn by Minne and Crittenden, 2015. Although the water and detergent cleaning frequency was much lower than that of the other coverings; the amount used per cleaning operation was higher, according to the specifications provided by the manufacturers' EPDs. Solely the maintenance stage accounted for $73 \%$ of the total life cycle impact of this FS in a medium traffic intensity scenario.

\subsection{Ozone layer depletion potential (ODP)}

The surveyed EPDs exhibited a great data scatter in this impact category, both in the product category itself and among the different categories. In all coverings, differences exceeding one or more orders of magnitude were found for the same category. For example, values ranging from $3.4 \mathrm{E}-11$ to $1.5 \mathrm{E}-06 \mathrm{~kg}$ CFC-11 eq. $/ \mathrm{m}^{2}$ were found for $\mathrm{WD}$, while values ranging from $7.9 \mathrm{E}-$ 09 to $2.8 \mathrm{E}-5 \mathrm{~kg} \mathrm{CFC}-11 \mathrm{eq} . / \mathrm{m}^{2}$ were found for PVC in the EPDs. This scatter meant that the results of the comparative analysis could vary if the outermost EPD values were taken. In this category, assuming a cradle-to-cradle scope, the FSs with inorganic coverings generated the greatest impact, with a difference of 2 orders of magnitude with respect to LAM, which yielded the best results. According to Bovea et al, 2010, the inorganic FS product stage by itself exhibited a higher potential impact, caused by the contribution of diesel vehicles in extraction and transport. In spite of the significant impacts exhibited by WD during the product stage, the recycling benefits obtained offset $67 \%$ of the manufacturing impacts (medium traffic scenario), thanks to its recycling ease and potential (Heisterberg-Moutsis et al., 2017). Once again, the TEX FS displayed the greatest impact because of the chemical agents containing chloromethane used in defoamer synthesis, applied in cleaning operations ( $76 \%$ of the total life cycle impact).

\subsection{Photochemical ozone creation potential (POCP)}

In a cradle-to-gate scenario, all coverings EPDs declared very similar impacts. In a cradle-tocradle scope, the inorganic FSs again exhibited the lowest environmental impact in every scenario (about 1.1E-02 kg ethene eq./FU), followed by PCV and LAM with quite similar values (3.3E-02 and 2.9E-02 kg ethene eq./FU, respectively), whose impact was mainly determined by the required replacements. These results differed from those obtained by Minne and Crittenden, 2015, which positioned vinyl slightly better than the ceramic covering, albeit without considering the FSs as a whole. In this impact category, TEX was also penalised by intensive use of cleaning agents, which matched the results obtained by Minne and Crittenden, 2015. The worst- 
performing FS was WD, which exhibited values ranging from $5.7 \mathrm{E}-02$ to $1.6 \mathrm{E}-01 \mathrm{~kg}$ ethene eq./FU, it being penalised by the repairs required during the entire RSP owing to VOCs (56\%) as well as to $\mathrm{NO}_{x}$ and $\mathrm{SO}_{2}$ emissions (44\%) generated by the solvents contained in the varnishes. For example, in a medium traffic scenario, WD needed 10 sanding and varnishing operations (with $0.33 \mathrm{~kg} / \mathrm{m}^{2}$ varnish/repair according to the consulted EPDs), accounting for $86 \%$ of the total service life impact. In this study, two types of specific parquet varnishes (namely solventbased and water-based varnishes) were considered, the impact of which was averaged; the choice of either one or the other could vary the contribution of this stage to the total life cycle impact by up to $\pm 7 \%$.

\subsection{Depletion potential for non-fossil resources (ADPE)}

The contribution to this impact category stemmed from raw materials extraction for the different coatings. Fig. 2 clearly evidences the high impact of TEX, for two main reasons: sulphur input in the manufacturing process (Thinkstep AG, 2018b) and the short lifespan. The former accounted for $23 \%$ of the total life cycle impact and the latter involved the need for 3 replacements in the RSP, therefore accounting for $73 \%$ (medium scenario). On the other hand, the PST product stage accounted for $93 \%$ of the total life cycle impact. These values stemmed from the use of raw materials such as borates, zinc and tin oxides in the manufacture of PST ceramic glazes (RosDosdá et al., 2018a). Wood-based and NS coverings performed best, LAM yielding the best results.

\subsection{Depletion potential for fossil resources (ADPF)}

In a cradle-to-gate scenario, the polymer coverings performed worst, matching the conclusions drawn by Jönsson et al., 1997. In this case TEX exhibited the greatest impact $\left(236 \mathrm{MJ} / \mathrm{m}^{2}\right)$ while wood-based coverings, WD and LAM, exhibited a lower impact $\left(100 \mathrm{MJ} / \mathrm{m} 2\right.$ and $113 \mathrm{MJ} / \mathrm{m}^{2}$, respectively), these values being similar to those obtained by Nebel et al., 2006. On extending the scope to the entire life cycle, inorganic FSs performed better, particularly in high traffic scenarios, with values of $290 \mathrm{MJ} / \mathrm{FU}$ and $357 \mathrm{MJ} / \mathrm{FU}$ for PST and NS, respectively. Analysis of each PST and NS stage revealed that the greatest differences occurred in the distribution stage. The distribution impact was basically determined by the specific weight (using the same means of transport and distance travelled), with values of $55.5 \mathrm{~kg} / \mathrm{m}^{2}$ and $24.1 \mathrm{~kg} / \mathrm{m}^{2}$ for NS and PST, respectively. The polymer coverings performed worst on extending the scope (cradle to cradle). TEX performed worst in every scenario owing to the environmental loads of raw materials supply (derived from crude oil), and manufacture (Günther and Langowski, 1997; Islam et al., 2015; Potting and Blok, 1995), thus directly affecting the 3 replacements required in the RSP. The necessary replacements and repairs involving the use of varnishes were primarily responsible for the WD impacts, WD being positioned as the second most unfavourable covering. 


\subsection{Weighting and normalisation}

Fig. 3 shows the weighted and normalised environmental impacts of the FSs life cycles for each scenario defined in the use stage according to the factors detailed in Table 10.

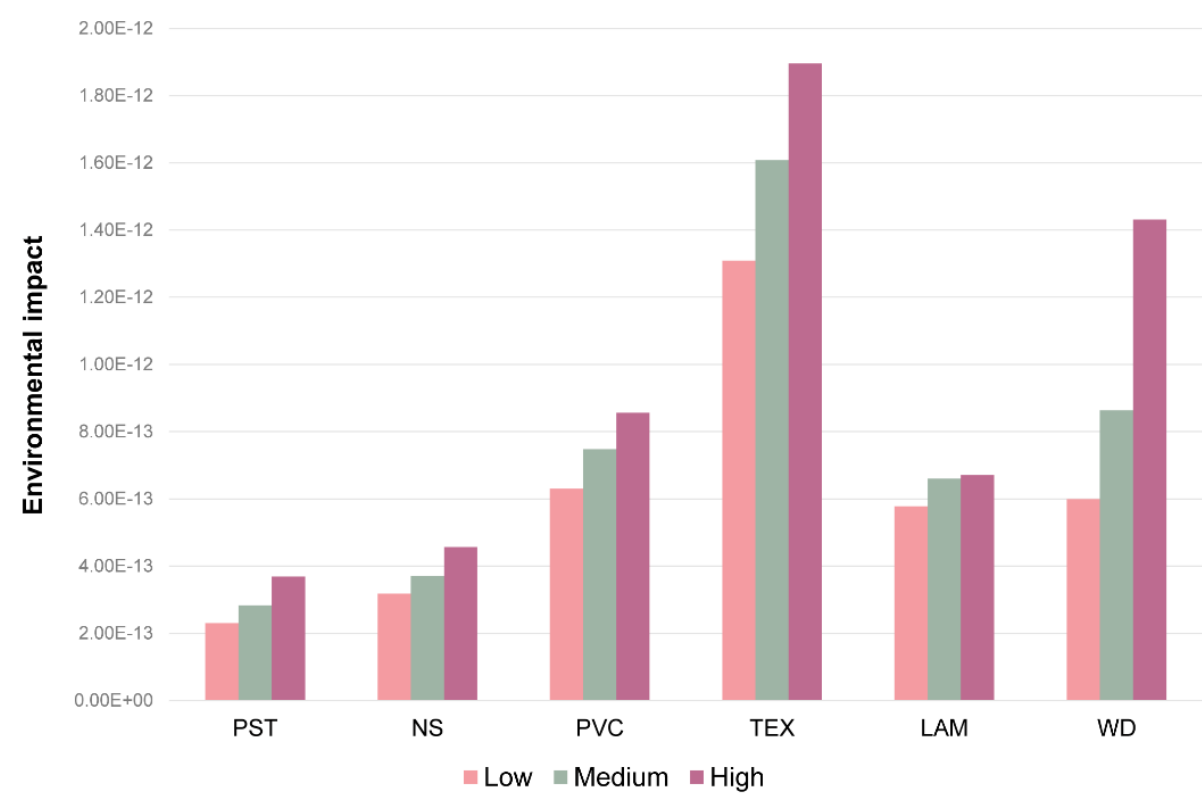

Fig. 3 Weighted and normalised values of the environmental impact results

The FSs with inorganic coverings (PST and NS) performed best, exhibiting differences of less than $5 \%$. These were followed by the FSs with LAM and PVC coverings, whose impact was $25 \%$ greater than that of the inorganic coverings, LAM and PVC exhibiting differences not exceeding $10 \%$. The FSs with WD coverings installed in low traffic areas exhibited a similar impact to that of LAM and PVC. However, the higher the traffic, the greater the impact, not just because the cleaning requirements increased but also because, with a greater number of repairs, WD service life decreased (Table 2).

In accordance with this methodology, TEX coverings exhibited the worst environmental performance, largely matching the results obtained in each impact category.

\subsection{Uncertainty and sensitivity analysis}

\subsubsection{Monte Carlo analysis}

A Monte Carlo analysis was applied to the entire life cycle of the FSs, using all EPDs starting data and every use scenario. Fig. 4 and Table 11 show the scatter in the results for each type of FS at $95 \%$ confidence level on performing 1000 iterations of the global warming potential values. The data are displayed in a box and whisker plot, simultaneously showing the central trend, scatter, and symmetry of the study data. The boxes represent the interquartile range between the 25th and 75th percentile ( $Q_{1}$ and $Q_{3}$, respectively); the cross $(X)$ represents the mean value; the line represents the median value corresponding to $\left(Q_{2}\right)$; and the whiskers represent the $95 \%$ confidence interval. 


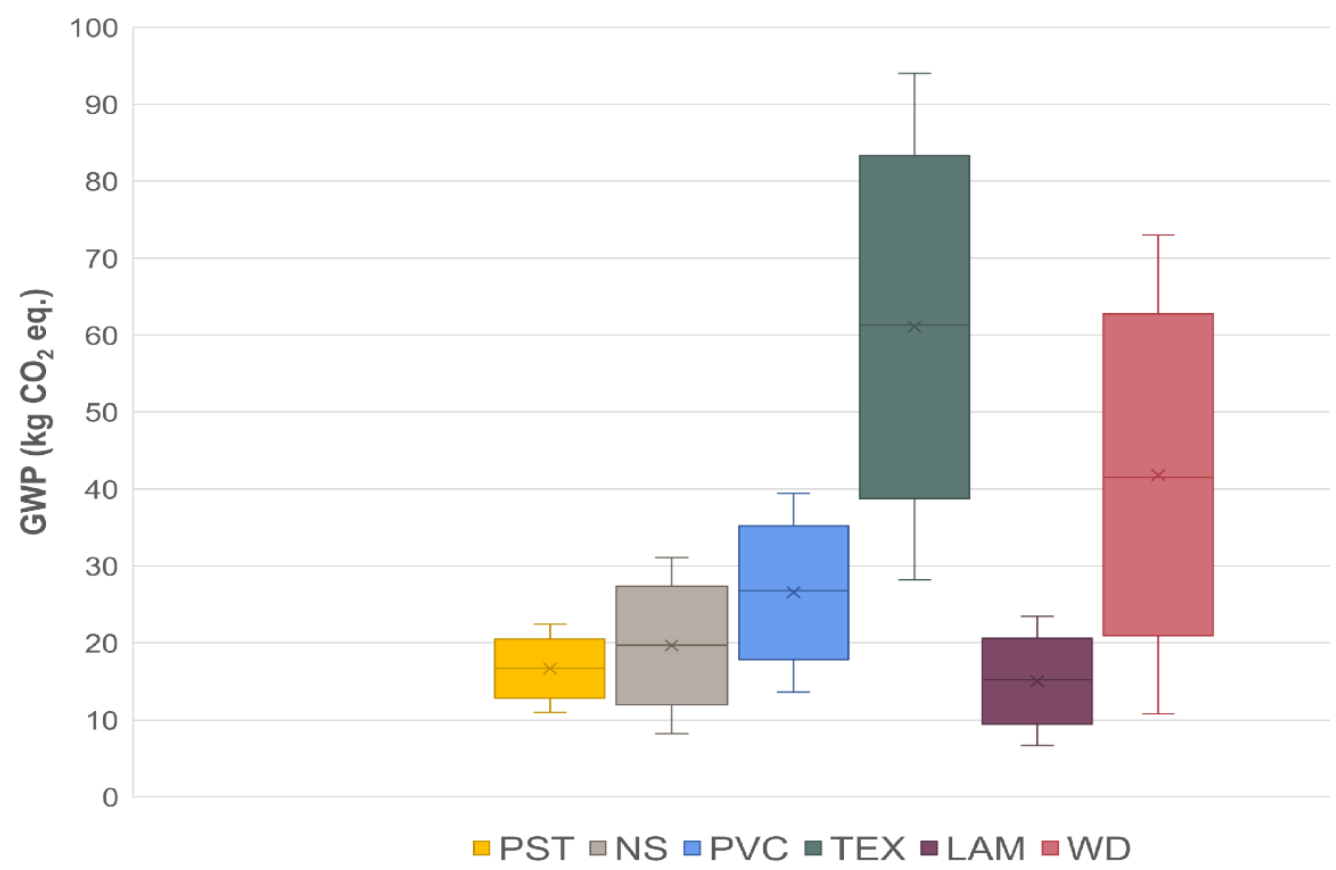

Fig. 4 Monte Carlo analysis of input/output variations in all FSs scenarios

Table 11 shows the number of EPDs used in the study, the mean, median, standard deviation (SD), and the 2.5 and 97.5 percentiles that limit the $95 \%$ confidence interval associated to each FS.

Table 11 Uncertainties for Global Warming Potential results related to each FS

\begin{tabular}{|c|c|c|c|c|c|c|}
\hline \multirow{2}{*}{ FS } & \multirow{2}{*}{$\begin{array}{c}\text { Number } \\
\text { of EPDs }\end{array}$} & Mean & \multirow{2}{*}{ Median } & SD & \multicolumn{2}{c|}{$\begin{array}{c}9 \% \text { confidence } \\
\text { interval }\end{array}$} \\
\cline { 6 - 8 } & & & & & Min & Max \\
\hline PST & 20 & 16.7 & 16.7 & 2.91 & 11.0 & 22.4 \\
\hline NS & 2 & 19.6 & 19.7 & 5.8 & 8.2 & 31.1 \\
\hline PVC & 14 & 26.5 & 26.8 & 6.6 & 13.6 & 39.4 \\
\hline TEX & 27 & 61.1 & 61.3 & 16.8 & 28.2 & 94 \\
\hline LAM & 5 & 15.1 & 15.2 & 4.3 & 6.7 & 23.4 \\
\hline WD & 5 & 41.9 & 41.5 & 15.9 & 10.8 & 73.0 \\
\hline
\end{tabular}

The samples were observed to be quite symmetrical and the mean and median values, when not identical, lay quite close to each other, evidencing the normality of the data distribution obtained by the Monte Carlo analysis.

TEX and WD were the FSs with the greatest data distribution in this impact category. The interquartile difference between $\mathrm{Q}_{3}-\mathrm{Q}_{1}$ is 23.3 y $21.5 \mathrm{~kg} \mathrm{CO} 2$ eq. respectively. This distribution might be due to the different product varieties included and hypothesis in the use stage (maintenance, repair and replacement). TEX included different densities, recycled material content, backings, etc. WD included solid and multilayer parquet. In the case of TEX, the median 
value and the value corresponding to the upper limit of the $95 \%$ confidence level were the highest in the FSs analysed.

LAM displayed the lowest contribution in values between the $25^{\text {th }}$ and $75^{\text {th }}$ percentile. This range overlapped by $70 \%$ with the PST values. PST exhibited the FS with the least uncertainty in this impact category.

\subsubsection{Scenario analysis}

Scenario analyses were performed to evaluate the influence and significance of some of the environmental parameters that had either been defined by assumptions or entailed significant life cycle impacts. The analyses focused in particular on maintenance operations in the coverings use stage, on length of service life and end-of-life management of the FS.

The operations relating to maintenance (cleaning) were defined by type of covering and pedestrian traffic intensity, the resulting impacts being mainly determined by: i) dry cleaning: electricity consumption in air extraction; ii) wet cleaning: water and detergent consumption.

Fig.5, shows the effect of a $99 \%$ reduction in detergent consumption in the maintenance stage of each studied FS. It was verified that the environmental impact categories most sensitive to detergent were ODP and EP. The contribution to ODP was practically determined in its entirety by the emission of chloromethane, used as a chemical intermediary in the production of silicone polymers added as antifoamers. Although the amount of chloromethane was very small (5.0E$05 \mathrm{~kg} / \mathrm{kg}$ detergent considered (Thinkstep AG, 2018b), it had a powerful destructive capacity on the ozone layer. The detergent's contribution to EP was principally influenced by the inorganic emissions of nitrogen compounds (mainly $\mathrm{NH}_{3}$ and $\mathrm{NO}_{x}$ ) and discharges into the water of phosphates and nitrogen compounds during their fabrication.
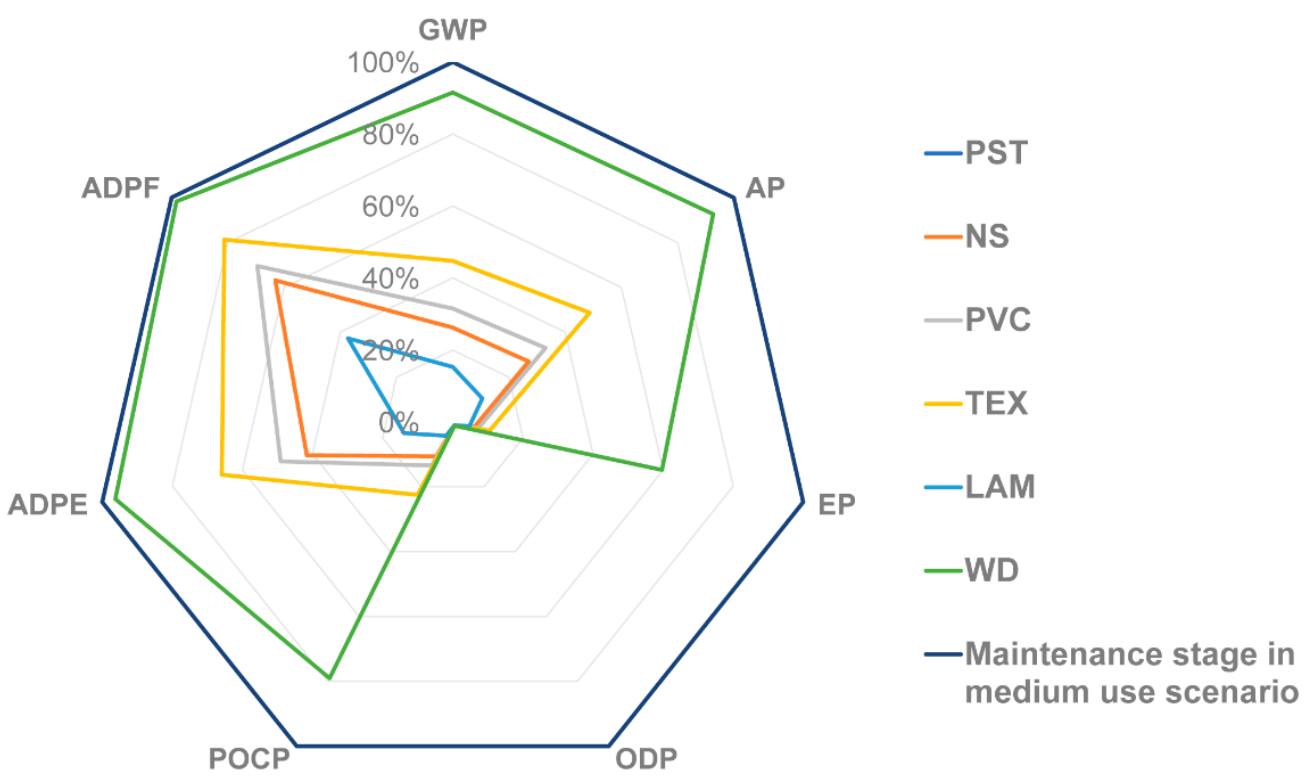

Fig. 5 Effect of $99 \%$ reduction in the amount of detergent on the environmental impacts of the maintenance stage in each type of FS 
In dry cleaning, a 99\% reduction in electricity consumption in a medium use scenario notably decreased the weighted and normalised values of the TEX and WD maintenance stage by 90 and $47 \%$, respectively. The most affected impact categories were ADPF and GWP owing to the make-up of the Spanish electricity mix, with a $44 \%$ fossil energy source (REE, 2018).

On the other hand, to analyse the contribution of the maintenance stage to that of the total life cycle, an analysis was performed in which the FS life cycle with and without this stage was compared. The weighted and normalised results obtained are shown in Fig.6. Note the great importance of this stage in TEX (accounting for $33 \%$ of the life cycle impact) because TEX cleaning required a much greater amount of detergent and energy than cleaning of the other FSs.

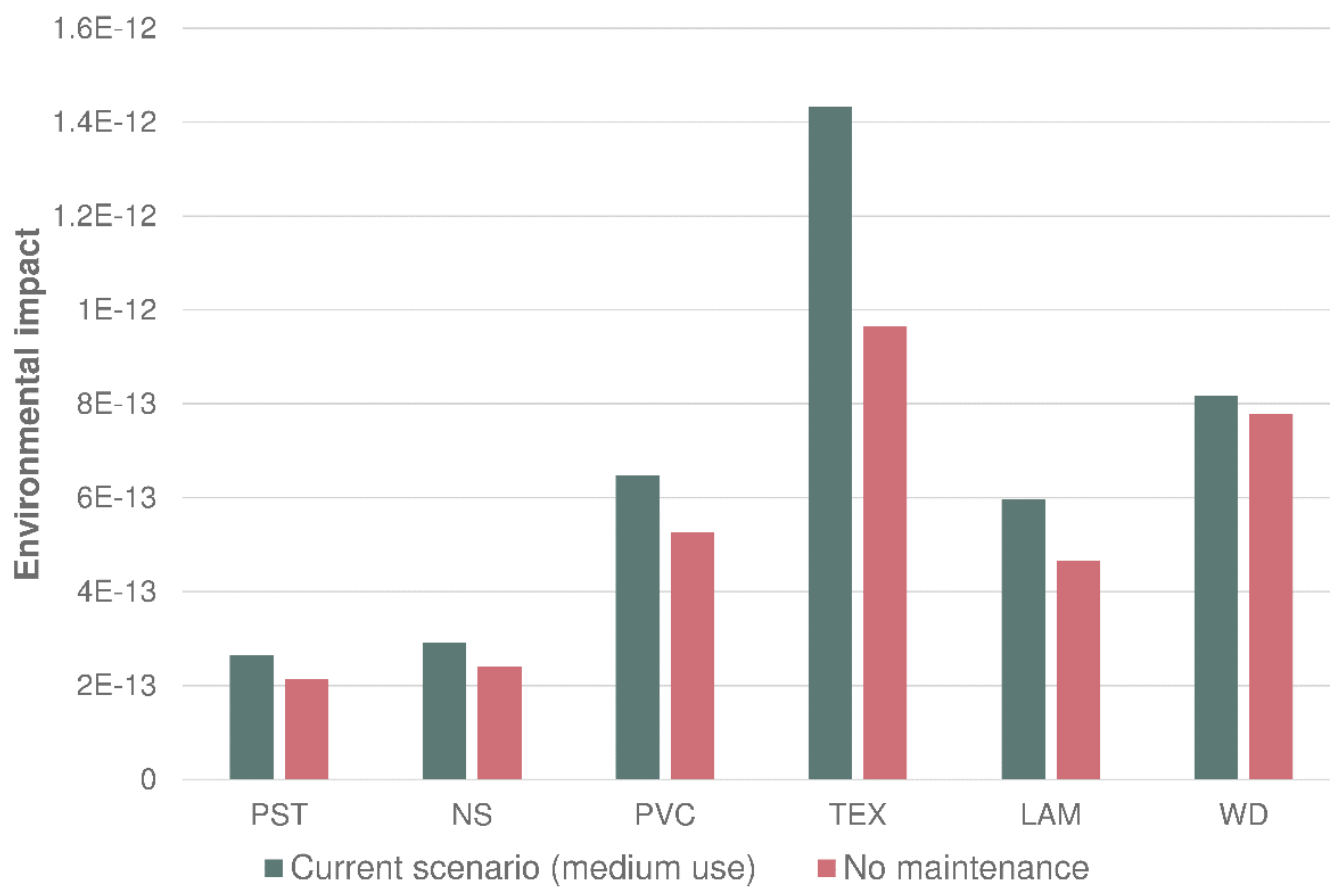

Fig.6 Comparative analysis of the weighted and normalised impacts of the FSs life cycle, considering the maintenance stage in a medium use scenario versus the FSs life cycle without a maintenance stage.

To analyse the influence of product service life, all the coverings were assumed to have an MSL of 15 years, so that the 50-year RSP required 3 replacements (Fig.7). The analysis showed that a premature replacement of the coverings that had a longer theoretical technical (or functional) service life (NS, PST, and WD) gave rise to significant increases in environmental impact $(+247$, 187 , and $134 \%$, respectively, in a medium use maintenance scenarios). 


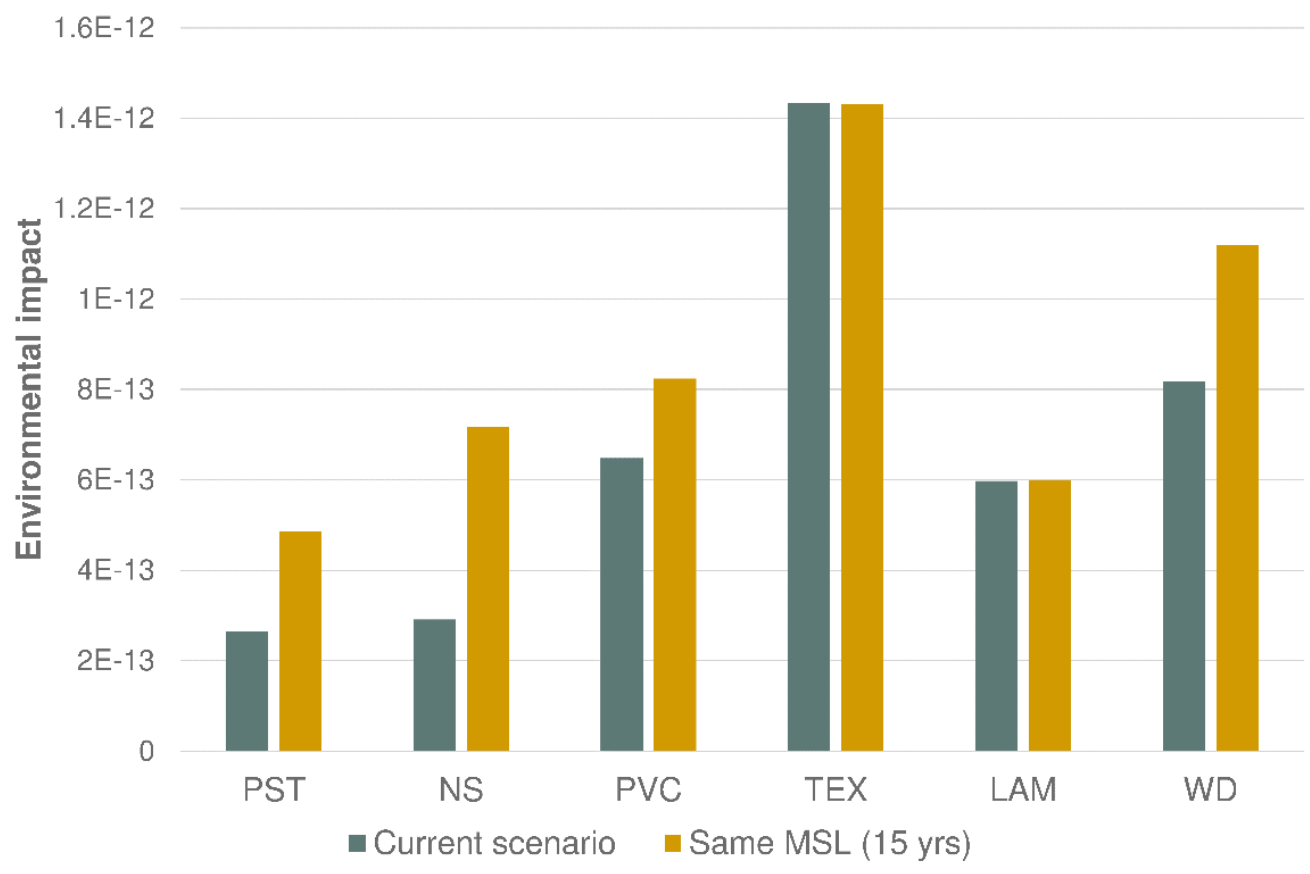

Fig.7 Environmental impacts of the studied FSs in a medium use scenario assuming a service life of 15 years.

Finally, the influence of the FS end-of-life scenarios has been analysed, considering the ideal hypothetical scenario (100\% recycling), considered in this study and the current recycling rate for the different materials according to Eurostat, 2019: 71\% for PST and NS; $89 \%$ for PVC; $79 \%$ for TEX; $0 \%$ for LAM; and $91 \%$ for WD.

Comparing both scenarios, all coverings show variations of less than $8 \%$ for all impact categories, except LAM, whose variation in GWP and POCP is $21 \%$ and $16 \%$, respectively, attributed to the methane emissions, originated in the decomposition of wood in landfills.

\section{Conclusions}

The method adopted in the study suggests that the use of EPDs as information source in comparative studies may be really useful, as was to be expected. However, their use currently requires high expertise in LCA and EPDs to avoid erroneous interpretations. To widen the use of this method for comparing materials with the same functionality, the following recommendations may be made to programs administrators: i) procedure harmonisation: verification methods, specific allocation rules, and criteria for obtaining the information provided by EPDs; and ii) scenario harmonisation beyond the gate, i.e. in the use and end-of-life stages.

Considering the background information, the methodology applied and the results obtained, the following recommendations may be made to EPD users when selecting building materials: i) always consider all the stages of the life cycle; ii) include in the analysis the rest of the elements of the construction systems in the context of the building; iii) include in the analysis products and operations necessary for the maintenance and repair of the construction solution; and iv) establish a reference study period and consider the material service life, being aware that an intentional shortening of the theoretical material service life will always lead to increases in environmental impacts. 
The inorganic floor coverings (PST, NS) behaved worst in the manufacturing stage in almost every impact category. However, they were least affected by pedestrian traffic intensity scenarios, as they required low-intensity maintenance operations and needed no replacement during the RSP. The whole life cycle of the FSs with inorganic coverings thus performed best in impact categories GWP, AP, EP, POCP, and ADPF.

The life cycle of the polymer FS, TEX, entailed the highest impacts in every impact category, except in POCP. The main contributions stemmed from the chemical agents used in wet cleaning operations (GWP, AP, EP, ODP) and the electricity consumed in vacuuming (GWP, AP, ADPF). In addition, the short lifespan played a key role.

In the wood-based FSs, WD appeared to be most affected by repair operations. The decrease in WD thickness from sanding/scraping, which shortened time between replacements and the use of varnish generated significant impacts on GWP, ADPF, and especially on POCP. LAM presented the most favourable results in ODP and ADPE.

Despite being classified in different groups in this study, LAM and PVC exhibited similar overall impacts in the rest of the impact categories, though their contribution came from different stages: while LAM had a shorter lifespan, the impacts from the PVC product stage were higher.

The application of normalisation and weighting factors allowed a simplified comparison to be made. According to this method, the inorganic FSs (PST and NS) performed best, followed by LAM and PVC whose impacts were, on average, 25\% higher. WD exhibited a similar impact to that of LAM and PVC in low traffic areas, while they clearly behaved worse in high-intensity traffic scenarios. TEX showed the worst environmental impact in all traffic scenarios.

The maintenance stage was probably the stage with the most subjective component and was one of the most influential stages in most FSs. A sensitivity analysis was therefore carried out varying the parameters that defined this stage. It was observed that detergent caused significant impacts on ODP and EP, while electricity did so on ADPF and GWP. This stage had a special relevance in TEX, as it accounted for $33 \%$ of its (normalised and weighted) impact. However, though omission of the cleaning operations reduced the absolute value in each impact category, it should be noted that it did not vary the relative position of the FSs. In this sense, a fundamental parameter in determining FSs position was service life (MSL), as it determined the number of replacements within the set time frame (RSP) and hence the magnitude of the related environmental impacts. In this study, these values were drawn from the consulted EPDs, which exhibited no significant scatter in this sense. A sensitivity analysis was performed matching the MSLs of all coverings, it being observed that premature substitution of coverings resulted in significant increases in environmental impact.

The Monte Carlo analysis showed that it was necessary to bear in mind that, though the comparisons were based on mean values, the same product category contained variations in product and/or impact, so that the results could not be individualised for each particular case.

\section{Acknowledgements}

This study was carried out with the financial support of the Castellón County Council through the SolconCer project https://solconcer.es, of the Valencia Institute for Business Competitiveness (IVACE) and the European Regional Development Fund [references IMAMCA/2015/1 and IMDEEA/2018/12], and of the European Commission through the LIFE+ Environment Policy and Governance programme [reference LIFE12 ENV/ES/230-LIFE CERAM]. 
The authors are responsible for the choice and presentation of the information contained in this paper as well as for the opinions expressed therein, which are not necessarily those of UNESCO and do not commit this Organization.

\section{Appendices}

The following complementary information is attached to the online version of this article:

- Literature review

- Analysis of the EPDs considered in this study

- Normalisation and Weighting

\section{References}

Abeysundara, U.G.Y., Babel, S., Piantanakulchai, M., 2009. A matrix for selecting sustainable floor coverings for buildings in Sri Lanka. J. Clean. Prod. 17, 231-238. https://doi.org/https://doi.org/10.1016/j.jclepro.2008.05.002

Akadiri, P.O., 2015. Understanding barriers affecting the selection of sustainable materials in building projects. J. Juild. https://doi.org/https://doi.org/10.1016/j.jobe.2015.08.006

Albertí, J., Balaguera, A., Brodhag, C., Fullana-i-Palmer, P., 2017. Towards life cycle sustainability assessment of cities. A review of background knowledge. Sci. Total Environ. 609, 1049-1063. https://doi.org/10.1016/j.scitotenv.2017.07.179

Albertí, J., Civancik-Uslu, D., Contessotto, D., Balaguera, A., Fullana-i-Palmer, P., 2019. Does a life cycle assessment remain valid after 20 years? Scenario analysis with a bus stop study. Resour. Conserv. Recycl. 144, 169-179. https://doi.org/https://doi.org/10.1016/j.resconrec.2019.01.041

Almeida, M.I., Dias, A.C., Demertzi, M., Arroja, L., 2016a. Environmental profile of ceramic tiles and their potential for improvement. J. Clean. Prod. 131, 583-593. https://doi.org/10.1016/j.jclepro.2016.04.131

Almeida, M.I., Dias, A.C., Demertzi, M., Arroja, L., 2016b. Environmental profile of ceramic tiles and their potential for improvement. J. Clean. Prod. 131, 583-593. https://doi.org/10.1016/j.jclepro.2016.04.131

Anand, C.K., Amor, B., 2017. Recent developments, future challenges and new research directions in LCA of buildings: A critical review. Renew. Sustain. Energy Rev. 67, 408-416. https://doi.org/10.1016/J.RSER.2016.09.058

Asif, M., Muneer, T., Kelley, R., 2007. Life cycle assessment: A case study of a dwelling home in Scotland. Build. Environ. 42 1391-1394. https://doi.org/https://doi.org/10.1016/j.buildenv.2005.11.023

Assiego de Larriva, R., Calleja Rodríguez, G., Cejudo López, J.M., Raugei, M., Fullana i Palmer, P., 2014. A decision-making LCA for energy refurbishment of buildings: Conditions of comfort. Energy Build. 70, 333-342. https://doi.org/10.1016/J.ENBUILD.2013.11.049

Balaguera, A., Carvajal, G.I., Albertí, J., Fullana-i-Palmer, P., 2018. Life cycle assessment of road construction alternative materials: A literature review. Resour. Conserv. Recycl. 132, 37-48. https://doi.org/https://doi.org/10.1016/j.resconrec.2018.01.003

Baraldi, L., 2017. World production and consumption of ceramic tiles. Ceram. world Rev. 123, 58-70 
Basbagill, J., Flager, F., Lepech, M., Fischer, M., 2013. Application of life-cycle assessment to early stage building design for reduced embodied environmental impacts. Build. Environ. 60, 8192. https://doi.org/https://doi.org/10.1016/j.buildenv.2012.11.009

Benveniste, G., Gazulla, C., Fullana, P., Celades, I., Ros, T., Zaera, V., Godes, B., 2011. Life cycle assessment and product category rules for the construction sector. The floor and wall tiles sector case study. Inf. la Construcción 63, 71-81. https://doi.org/10.3989/ic.10.034

Bovea, M.D., Díaz-Albo, E., Gallardo, A., Colomer, F.J., Serrano, J., 2010. Environmental performance of ceramic tiles: Improvement proposals. Mater. Des. 31, 35-41. https://doi.org/10.1016/j.matdes.2009.07.021

Bovea, M.D., Ibáñez-Forés, V., Agustí-Juan, I., 2014. Environmental product declaration (EPD) labelling of construction and building materials. Eco-efficient Constr. Build. Mater. 125-150. https://doi.org/10.1533/9780857097729.1.125

Bovea, M.-D., Saura, Ú., Ferrero, J.L., Giner, J., 2007. Cradle-to-gate study of red clay for use in the ceramic industry. Int. J. Life Cycle Assess. 12, 439. https://doi.org/https://doi.org/10.1065/lca2006.06.252

Capros, P., De Vita, A., Tasios, N., Papadopoulos, D., Siskos, P., Apostolaki, E., Zampara, M., Paroussos, L., Fragiadakis, K., Kouvaritakis, N., 2013. EU energy, transport and GHG emissions: trends to 2050, reference scenario 2013. European Commission, Directorate-General for Energy, Directorate-General for Climate Action and Directorate-General for Mobility and Transport, Luxembourg. https://doi.org/10.2833/17897

Carlo Montani, 2018. XXVIII World Marble and Stones Report 2017. Aldus Casa di Edizioni, Carrara, Italy

CET, 2014. - European Ceramic Tile Manufacturer's Federation. Product Category Rules for preparing an Environmental Product Declaration for Ceramic tiles. Brussels, Belgium

Chang, D., Lee, C.K.M., Chen, C.-H., 2014. Review of life cycle assessment towards sustainable product development. J. Clean. Prod. 83, 48-60. https://doi.org/https://doi.org/10.1016/j.jclepro.2014.07.050

COM/2011/0571 final, 2011. Roadmap to a Resource Efficient Europe. Communication from the Commission to the European Parliament, the Council, the European Economic and Social Committee and the Committee of the Regions

COM/2014/445 final, 2014. Resource Efficiency Opportunities in the Building Sector. Communication from the Commission to the European Parliament, the Council, the European Economic and Social Committee and the Committee of the Regions

COM/2015/0614 final, 2015. Closing the loop - An EU action plan for the Circular Economy. Communication from the Commission to the European Parliament, the Council, the European Economic and Social Committee and the Committee of the Regions

Cuéllar-Franca, R.M., Azapagic, A., 2012. Environmental impacts of the UK residential sector: Life cycle assessment of houses. Build. Environ. 54, 86-99. https://doi.org/https://doi.org/10.1016/j.buildenv.2012.02.005

CYPE Ingenieros, S.A., 2018. Generador de precios de la construcción. España [WWW Document]. URL http://www.generadordeprecios.info/ (accessed 10.9.18). (In Spanish)

DAPconstrucción $囚, 2015$. RCP 002, v2. Reglas de Categoría de Producto para preparar una Declaración Ambiental de Producto (DAPcons) sobre productos de revestimiento cerámico (in Spanish). 
Diputación de Castellón, 2018. Solconcer. Caracterización de Soluciones Constructivas [WWW Document]. URL http://solconcer.es/ (accessed 10.9.18). (In Spanish)

EN 12058, 2015. Natural stone products - Slabs for floors and stairs - Requirements. European Standards

EN 1307+A1, 2016. Textile floor coverings - Classification. European Standards

EN 13329, 2017. Laminate floor coverings - Elements with a surface layer based on aminoplastic thermosetting resins - Specifications, requirements and test methods (includes Amendment :2017). European Standards

EN 14342, 2013. Wood flooring - Characteristics, evaluation of conformity and marking. European Standards

EN 15804+A1, 2013. Sustainability of construction works - Environmental product declarations - Core rules for the product category of construction products. CEN European Commission, Brussels, Belgium

EN 15978, 2011. Sustainability of construction works - Assessment of environmental performance of buildings - Calculation method. European Standards

European Carpet and Rug Association (ECRA), 2018. The European Carpet Market [WWW Document]. URL http://www.ecra.eu/ (accessed 7.23.18)

European Federation of the Parquet Industry (FEP), 2017. The European Parquet Industries in 2016 [WWW Document]. URL http://www.parquet.net/files/2017___FEP_-_Market__June_PR.pdf (accessed 7.25.18)

European Producers of Laminate Flooring (EPLF), 2018. Market Statistics [WWW Document]. URL https://www.eplf.com/sites/default/files/downloads/elnd1802_b17_eplf_sales2017_press.pdf (accessed 7.25.18)

Eurostat, 2019. Treatment of waste by waste category, hazardousness and waste management operations [env_wastrt] [WWW Document]. Eur. Comm. URL http://appsso.eurostat.ec.europa.eu/nui/show.do?dataset=env_wastrt\&lang=en (Accessed 06.26.2019)

Fazeni, K., Lindorfer, J., Prammer, H., 2014. Methodological advancements in life cycle process design: a preliminary outlook. Resour. Conserv. Recycl. 92, 66-77. https://doi.org/https://doi.org/10.1016/j.resconrec.2014.08.011

Fila Industria Chimica S.p.A., 2018. Fila Industria Chimica S.p.A. [WWW Document]. URL https://www.filasolutions.com/ (accessed 1.31.19)

Floor covering weekly, 2018. Statistical Report 2017. Floor Cover. Wkly. 67

Frischknecht, R., 2010. LCI modelling approaches applied on recycling of materials in view of environmental sustainability, risk perception and eco-efficiency. Int. J. Life Cycle Assess. 15, 666-671. https://doi.org/10.1007/s11367-010-0201-6

Ganassali, S., Lavagna, M., Campioli, A., Saporetti, S., 2018. Green Public Procurement and Construction Sector: EPD and LCA based benchmarks of the whole-building, in: Designing Sustainable Technologies, Products and Policies. Springer, pp. 503-513. https://doi.org/https://doi.org/10.1007/978-3-319-66981-6_5

Gazi, A., Skevis, G., Founti, M.A., 2012. Energy efficiency and environmental assessment of a typical marble quarry and processing plant. J. Clean. Prod. 32, 10-21. https://doi.org/https://doi.org/10.1016/j.jclepro.2012.03.007 
Gazulla Santos, C., 2012. Declaraciones ambientales de producto instrumento para la mejora de productos. PhD thesis. UNESCO Chair Life Cycle Clim. Chang. ESCI-UPF Inst. Ciència i Tecnol. Ambient. Dr. en Ciència i Tecnol. Ambient. Univ. Autònoma Barcelona. (In Spanish)

Gelowitz, M.D.C., McArthur, J.J., 2017. Comparison of type III environmental product declarations for construction products: Material sourcing and harmonization evaluation. J. Clean. Prod. 157, 125-133. https://doi.org/https://doi.org/10.1016/j.jclepro.2017.04.133

Gelowitz, M.D.C., McArthur, J.J., 2016. Investigating the Effect of Environmental Product Declaration Adoption in LEED $\otimes$ on the Construction Industry: A Case Study. Procedia Eng. 145, 58-65. https://doi.org/10.1016/J.PROENG.2016.04.014

GlobalEPD, 2018. RCP 002, v2. Regla de Categoría de Producto de Recubrimientos cerámicos. Madrid. (In Spanish)

Günther, A., Langowski, H.-C., 1997. Life cycle assessment study on resilient floor coverings. Int. J. Life Cycle Assess. 2, 73-80. https://doi.org/https://doi.org/10.1007/BF02978763

Häfliger, I.-F., John, V., Passer, A., Lasvaux, S., Hoxha, E., Saade, M.R.M., Habert, G., 2017. Buildings environmental impacts' sensitivity related to LCA modelling choices of construction materials. J. Clean. Prod. 156, 805-816. https://doi.org/10.1016/J.JCLEPRO.2017.04.052

Heisterberg-Moutsis, G., Heinz, R., Wolf, T.F., Harper, D.J., James, D., Mazzur, R.P., Kettler, V., Soiné, H., Peoples, R., 2017. Floor Coverings. Ullmann's Encycl. Ind. Chem. 1-26. https://doi.org/https://doi.org/10.1002/14356007.a11_263.pub2

Hill, C., Norton, A., Dibdiakova, J., 2018. A comparison of the environmental impacts of different categories of insulation materials. Energy Build. 162, 12-20. https://doi.org/https://doi.org/10.1016/j.enbuild.2017.12.009

Holzmann maschinen $\mathrm{GmbH}$, 2018. Holzmann maschinen GmbH [WWW Document]. URL https://www.holzmann-maschinen.at (accessed 1.31.19)

Hunsager, E.A., Bach, M., Breuer, L., 2014. An institutional analysis of EPD programs and a global PCR registry. Int. J. Life Cycle Assess. 19, 786-795. https://doi.org/10.1007/s11367-0140711-8

Ibáñez-Forés, V., Bovea, M.-D., Simó, A., 2011. Life cycle assessment of ceramic tiles. Environmental and statistical analysis. Int. J. Life Cycle Assess. 16, 916-928. https://doi.org/10.1007/s11367-011-0322-6

IEE Project TABULA, 2012. Typology Approach for Building Stock Energy Assessment [WWW Document]. URL http://webtool.building-typology.eu/\#bm (accessed 10.9.18)

IETcc-CSIC, 2011. Catálogo de elementos constructivos del Código Técnico de la Edificación. Ministerio de Fomento de España, Madrid. (In Spanish)

Institut Bauen und Umwelt e.V., 2017. Part B: Requirements on the EPD for Ceramic tiles and panels. Berlin.

Institut Bauen und Umwelt e.V., 2017. Part B: Requirements on the EPD for Synthetic carpet yarns. Berlin.

Iribarren, D., Marvuglia, A., Hild, P., Guiton, M., Popovici, E., Benetto, E., 2015. Life cycle assessment and data envelopment analysis approach for the selection of building components according to their environmental impact efficiency: a case study for external walls. J. Clean. Prod. 87, 707-716. https://doi.org/https://doi.org/10.1016/j.jclepro.2014.10.073

Islam, H., Jollands, M., Setunge, S., Haque, N., Bhuiyan, M.A., 2015. Life cycle assessment and life cycle cost implications for roofing and floor designs in residential buildings. Energy Build. 104, 250-263. https://doi.org/10.1016/j.enbuild.2015.07.017 
ISO 10581, 2011. Resilient floor coverings -- Homogeneous poly(vinyl chloride) floor covering -Specifications, 1st ed. International Organization for Standardization

ISO 10582, 2017. Resilient floor coverings -- Heterogeneous poly(vinyl chloride) floor covering - Specifications, 2nd ed. International Organization for Standardization

ISO 13006, 2012. Ceramic tiles - Definitions, classification, characteristics and marking, 2nd ed. International Organization for Standardization, USA

ISO 14025, 2006. Environmental labels and declarations -- Type III environmental declarations - Principles and procedures, 1st ed. International Organization for Standardization

ISO 14040, 2006. Environmental management -- Life cycle assessment -- Principles and framework, 2nd ed. International Organization for Standardization, Geneva.

ISO 14044, 2006. Environmental management -- Life cycle assessment -- Requirements and guidelines. International Organization for Standardization, Geneva

ISO 21930, 2017. Sustainability in buildings and civil engineering works -- Core rules for environmental product declarations of construction products and services, 2nd ed. International Organization for Standardization

Joint Research Centre, 2015. European Reference Life-Cycle Database. Version 3.2. [WWW Document]. URL http://eplca.jrc.ec.europa.eu/ELCD3/processList.xhtml (accessed 5.16.16)

Jönsson, Å., 1999. Including the use phase in LCA of floor coverings. Int. J. Life Cycle Assess. 4, 321-328. https://doi.org/https://doi.org/10.1007/BF02978521

Jönsson, Å., Tillman, A.-M., Svensson, T., 1997. Life cycle assessment of flooring materials: case study. Build. Environ. 32, 245-255

Jungmeier, G., Werner, F., Jarnehammar, A., Hohenthal, C., Richter, K., 2002. Allocation in LCA of wood-based products experiences of cost action E9. Int. J. Life Cycle Assess. 7, 369-375. https://doi.org/10.1007/BF02978686

Khasreen, M.M., Banfill, P.F.G., Menzies, G.F., 2009. Life-cycle assessment and the environmental impact of buildings: a review. Sustainability 1, 674-701

Lasvaux, S., Gantner, J., Wittstock, B., Bazzana, M., Schiopu, N., Saunders, T., Gazulla, C., Mundy, J.A., Sjöström, C., Fullana-i-Palmer, P., 2014. Achieving consistency in life cycle assessment practice within the European construction sector: the role of the EeBGuide InfoHub. Int. J. Life Cycle Assess. 19, 1783-1793. https://doi.org/https://doi.org/10.1007/s11367-0140786-2

Laurin, L., Amor, B., Bachmann, T.M., Bare, J., Koffler, C., Genest, S., Preiss, P., Pierce, J., Satterfield, B., Vigon, B., 2016. Life cycle assessment capacity roadmap (section 1): decisionmaking support using LCA. Int. J. Life Cycle Assess. 21, 443-447. https://doi.org/10.1007/s11367-016-1031-y

Mercante, I.T., Bovea, M.D., Ibáñez-Forés, V., Arena, A.P., 2012. Life cycle assessment of construction and demolition waste management systems: a Spanish case study. Int. J. Life Cycle Assess. 17, 232-241. https://doi.org/10.1007/s11367-011-0350-2

Ministerio de Fomento de España, 2011. Documentos básicos del Código Técnico de la Edificación [WWW Document]. URL https://www.codigotecnico.org/ (In Spanish)

Ministerio de Fomento de España, 2009. Documento Básico DB-HR Protección frente al ruido del Código Técnico de la Edificación / Apartado 3.1.2.3.5 Condiciones mínimas de los elementos de separación horizontales (In Spanish) 
Minkov, N., Schneider, L., Lehmann, A., Finkbeiner, M., 2015. Type III Environmental Declaration Programmes and harmonization of product category rules: status quo and practical challenges. J. Clean. Prod. 94, 235-246. https://doi.org/https://doi.org/10.1016/j.jclepro.2015.02.012

Minne, E., Crittenden, J.C., 2015. Impact of maintenance on life cycle impact and cost assessment for residential flooring options. Int. J. Life Cycle Assess. 20, 36-45. https://doi.org/10.1007/s11367-014-0809-z

Monfort, E., 2012. What role do Ceramic Tiles play in Green Procurement and Sustainable Building?, in: World Congress on Ceramic Tile Quiality-Qualicer. Castelló, Spain

Nebel, B., Cowell, S.J., 2003. Global warming reduction potential of biomass based products: an example of wood products, in: Proceedings of the XXth SETAC-Europe Annual Meeting. p. 49

Nebel, B., Zimmer, B., Wegener, G., 2006. Life cycle assessment of wood floor coverings-a representative study for the german flooring industry. Int. J. life cycle Assess. 11, 172-182. https://doi.org/https://doi.org/10.1065/lca2004.10.187

Nicoletti, G.M., Notarnicola, B., Tassielli, G., 2002. Comparative Life Cycle Assessment of flooring materials: ceramic versus marble tiles. J. Clean. Prod. 10, 283-296. https://doi.org/10.1016/S0959-6526(01)00028-2

Ortiz, O., Castells, F., Sonnemann, G., 2009. Sustainability in the construction industry: A review of recent developments based on LCA. Constr. Build. Mater. 23, 28-39. https://doi.org/https://doi.org/10.1016/j.conbuildmat.2007.11.012

Parador GmbH \& Co.KG, 2013. Environmental Product Declaration, PD-PAR-20130290-IBC2EN. Coesfeld, Germany

Passer, A., Lasvaux, S., Allacker, K., De Lathauwer, D., Spirinckx, C., Wittstock, B., Kellenberger, D., Gschösser, F., Wall, J., Wallbaum, H., 2015. Environmental product declarations entering the building sector: critical reflections based on 5 to 10 years experience in different European countries. Int. J. Life Cycle Assess. 20, 1199-1212. https://doi.org/10.1007/s11367-015-0926-3

Paulsen, J., 1999. Service life prediction for floor coverings. Durab. Build. Mater. components. Ottawa NRC 1467-1474

Pini, M., Ferrari, A.M., Gamberini, R., Neri, P., Rimini, B., 2014. Life cycle assessment of a large, thin ceramic tile with advantageous technological properties. Int. J. Life Cycle Assess. 19, 15671580. https://doi.org/10.1007/s11367-014-0764-8

Potting, J., Blok, K., 1995. Life-cycle assessment of four types of floor covering. J. Clean. Prod. 3, 201-213. https://doi.org/https://doi.org/10.1016/0959-6526(95)00082-8

Puig, R., Kiliç, E., Navarro, A., Albertí, J., Chacón, L., Fullana-i-Palmer, P., 2017. Inventory analysis and carbon footprint of coastland-hotel services: A Spanish case study. Sci. Total Environ. 595, 244-254. https://doi.org/https://doi.org/10.1016/j.scitotenv.2017.03.245

REE Red Eléctrica de España, 2018. Informe del sistema eléctrico español 2017 [WWW Document].

URL https://www.ree.es/sites/default/files/11_PUBLICACIONES/Documentos/InformesSistemaElect rico/2017/inf_sis_elec_ree_2017.pdf (accessed 5.9.19).

Regulation (EU) No 305/2011, 2011. European Parliament and of the Council of 9 March 2011 laying down harmonised conditions for the marketing of construction products and repealing Council Directive 89/106/EEC

Reza, B., Sadiq, R., Hewage, K., 2011. Sustainability assessment of flooring systems in the city of Tehran: An AHP-based life cycle analysis. Constr. Build. Mater. 25, 2053-2066. https://doi.org/https://doi.org/10.1016/j.conbuildmat.2010.11.041 
Ros-Dosdá, T., Celades, I., Monfort, E., Fullana-i-Palmer, P., 2018a. Environmental profile of Spanish porcelain stoneware tiles. Int. J. Life Cycle Assess. 23, 1562-1580. https://doi.org/10.1007/s11367-017-1377-9

Ros-Dosdá, T., Fullana-i-Palmer, P., Mezquita, A., Masoni, P., Monfort, E., 2018b. How can the European ceramic tile industry meet the EU's low-carbon targets? A life cycle perspective. J. Clean. Prod. 199, 554-564. https://doi.org/https://doi.org/10.1016/j.jclepro.2018.07.176

Saarela, K., 1999. Emission from floor coverings. Org. Indoor Air Pollut. Occur. 185-202. https://doi.org/https://doi.org/10.1002/9783527613663.ch14

Silvestre, J.D., De Brito, J., Pinheiro, M.D., 2014. Environmental impacts and benefits of the endof-life of building materials-calculation rules, results and contribution to a "cradle to cradle" life cycle. J. Clean. Prod. 66, 37-45. https://doi.org/https://doi.org/10.1016/j.jclepro.2013.10.028

Sollinger, S., Levsen, K., Wünsch, G., 1993. Indoor air pollution by organic emissions from textile floor coverings. Climate chamber studies under dynamic conditions. Atmos. Environ. Part B. Urban Atmos. 27, 183-192. https://doi.org/10.1016/0957-1272(93)90004-P

Thinkstep AG, 2018a. GaBi Software-system. Compilation 8.0.718 [WWW Document]. URL http://www.gabi-software.com/software/ (accessed 5.17.16)

Thinkstep AG, 2018b. Database for Life Cycle Engineering. Professional + Construction materials extension (version 8007)

Thuring M.; Spirinckx C.; Debacke W., 2013. PCR-TBE. Product Category Rules for Environmental Product Declarations for Construction Clay Products. Mol, Belgium

Tikul, N., Srichandr, P., 2010. Assessing the environmental impact of ceramic tile production in Thailand. J. Ceram. Soc. Japan 118, 887-894. https://doi.org/10.2109/jcersj2.118.887

Traverso, M., Rizzo, G., Finkbeiner, M., 2010. Environmental performance of building materials: life cycle assessment of a typical Sicilian marble. Int. J. Life Cycle Assess. 15, 104. https://doi.org/10.1007/s11367-009-0135-z

Tuomainen, A., Seuri, M., Sieppi, A., 2004. Indoor air quality and health problems associated with damp floor coverings. Int. Arch. Occup. Environ. Health 77, 222-226. https://doi.org/10.1007/s00420-003-0481-2

Wolf, M.-A., Chomkhamsri, K., Brandao, M., Pant, R., Ardente, F., Pennington, D.W., Manfredi, S., de Camillis, C., Goralczyk, M., 2010. ILCD Handbook-General Guide for Life Cycle Assessment-Detailed Guidance. https://doi.org/10.2788/38479

Zabalza Bribián, I., Aranda Usón, A., Scarpellini, S., 2009. Life cycle assessment in buildings: State-of-the-art and simplified LCA methodology as a complement for building certification. Build. Environ. 44, 2510-2520. https://doi.org/10.1016/J.BUILDENV.2009.05.001

Zabalza, I., Valero, A., Aranda, A., 2011. Life cycle assessment of building materials: Comparative analysis of energy and environmental impacts and evaluation of the eco-efficiency improvement potential. Build. Environ. 46, 1133-1140. https://doi.org/https://doi.org/10.1016/j.buildenv.2010.12.002 


\section{Appendix 1:}

Literature review 
Table A1.1 Literature review

\begin{tabular}{|c|c|c|c|c|c|}
\hline Reference & Coverings & Environmental impact categories & Evaluation method & Scope/limits & Functional Unit \\
\hline Jönsson et al., 1997 & $\begin{array}{l}\text { Linoleum } \\
\text { Vinyl } \\
\text { Wood }\end{array}$ & $\begin{array}{l}\text { Resouce use } \\
\text { Energy use } \\
\text { Emissions to the air } \\
\text { Waste generation }\end{array}$ & $\begin{array}{l}\text { EPS (Environmental Priority } \\
\text { Strategies in product design) } \\
\text { Environmental Theme method } \\
\text { Ecological Scarcity method }\end{array}$ & Cradle to grave & $\begin{array}{l}\text { The covering of one square meter of flooring } \\
\text { during one year of operation }\end{array}$ \\
\hline $\begin{array}{l}\text { Potting and Block, } \\
1997\end{array}$ & $\begin{array}{l}\text { Cushion vinyl } \\
\text { Woollen carpet } \\
\text { PA carpet } \\
\text { Linoleum }\end{array}$ & $\begin{array}{l}\mathrm{CED}(\mathrm{MJ}) \\
\mathrm{GWP}\left(\mathrm{g} \mathrm{CO}_{2} \text { eq.) }\right. \\
\mathrm{EP}\left(\mathrm{g} \mathrm{PO}_{4}^{3-} \text { eq.) }\right. \\
\mathrm{AP}\left(\mathrm{g} \mathrm{SO}_{2} \text { eq.) }\right. \\
\mathrm{POCP} \text { (g ethylene eq.) } \\
\text { Waste (g hazardous and } \mathrm{g} \text { non- } \\
\text { hazardous) }\end{array}$ & $\begin{array}{l}\text { CED: From (1) and (2) } \\
\text { GWP, EP, AP, POCP: from (3) }\end{array}$ & $\begin{array}{l}\text { Extraction and processing of raw } \\
\text { materials; use (only lifespan, no } \\
\text { maintenance); and waste processing }\end{array}$ & $\begin{array}{l}\text { 'The amount of floor covering of good quality } \\
\text { which is needed to cover one } \mathrm{m}^{2} \text { of floor } \\
\text { surface in a normal Dutch house over a } \\
\text { period of } 15 \text { years'. }\end{array}$ \\
\hline $\begin{array}{l}\text { Günther and } \\
\text { Langowski, } 1997\end{array}$ & $\begin{array}{l}\text { PVC } \\
\text { Cushioned PVC } \\
\text { Polyolefins } \\
\text { Parquet } \\
\text { Linoleum } \\
\text { Rubber } \\
\text { Textile }\end{array}$ & $\begin{array}{l}\text { Gross energy }(\mathrm{MJ}) \\
\text { Water demand }\left(\mathrm{m}^{3}\right) \\
\text { Municipal and chemical waste } \\
(\mathrm{kg}) \\
\mathrm{AP}(\mathrm{Mol} \mathrm{H}+) \\
\mathrm{GWP}\left(\mathrm{kg} \mathrm{CO}_{2}\right)\end{array}$ & "Münchner Kreis" & Cradle to grave & $\begin{array}{l}\text { The typical use of } 20 \mathrm{~m}^{2} \text { flooring over a period } \\
\text { of } 20 \text { years }\end{array}$ \\
\hline Nicoletti et al., 2002 & $\begin{array}{l}\text { Marble tile } \\
\text { Ceramic tile }\end{array}$ & $\begin{array}{l}\text { ADP, GWP, ODP, HT, ECA, AP, } \\
\text { POCP, NP }\end{array}$ & $\begin{array}{l}\text { Heijungs et al., } 1992 \text { (3) } \\
\text { IPPC (4) } \\
\text { Normalization (5) } \\
\text { Weighting (6) }\end{array}$ & $\begin{array}{l}\text { Extraction, manufacturing, disposal in } \\
\text { landfills. Excluding: fixing materials; } \\
\text { cleaning operation; ceramic: lime from the } \\
\text { abatement of combustion fumes and } \\
\text { sludge waste; marble: wax and diamond } \\
\text { wire }\end{array}$ & $1 \mathrm{~m}^{2}$ of flooring tile over a period of 40 years \\
\hline
\end{tabular}




\begin{tabular}{|c|c|c|c|c|c|}
\hline Reference & Coverings & Environmental impact categories & Evaluation method & Scope/limits & Functional Unit \\
\hline Nebel et al., 2006 & $\begin{array}{l}8 \mathrm{~mm} \text { parquet } \\
10 \mathrm{~mm} \text { parquet } \\
22 \mathrm{~mm} \text { parquet } \\
\text { Multilayer parquet } \\
\text { (floated) } \\
\text { Multilayer parquet } \\
\text { (glued) } \\
\text { Floor wood boards } \\
\text { Wood blocks }\end{array}$ & $\begin{array}{l}\mathrm{GWP} \text { ( } \mathrm{g} \mathrm{CO}_{2} \text { eq.) } \\
\mathrm{EP}\left(\mathrm{g} \mathrm{PO}_{4}^{3-} \text { eq.) }\right. \\
\mathrm{AP} \text { ( } \mathrm{g} \mathrm{SO}_{2} \text { eq.) } \\
\mathrm{POCP} \text { (g ethylene eq.) } \\
\text { ODP (CFC11-eq.) } \\
\text { Primary Energy (MJ) }\end{array}$ & Guinée et al., 2002 (7) & $\begin{array}{l}\text { Cradle to grave. Regular cleaning excluded } \\
\text { but vacuum once a week is considered in } \\
\text { the sensitivity analysis. Exclusion } f \text { oil and } \\
\text { wax finish }\end{array}$ & $\begin{array}{l}1 \mathrm{~m}^{2} \text { of laid wood floor covering assuming } \\
\text { average wear and tear in a home that is } \\
\text { completely refurbished after } 50 \text { years }\end{array}$ \\
\hline $\begin{array}{l}\text { Abeysundara et al., } \\
2009\end{array}$ & $\begin{array}{l}\text { Ceramic tile } \\
\text { Vinyl tile }\end{array}$ & $\begin{array}{l}\mathrm{GWP} \text { (kg CO} 2 \text { eq.) } \\
\mathrm{AP} \text { ( } \mathrm{kg} \mathrm{SO}_{2} \text { eq.) } \\
\text { Nutrient enrichment potential ( } \mathrm{kg} \\
\mathrm{SO}_{2} \text { eq.) }\end{array}$ & Wenzel et al., 1997 (8) & $\begin{array}{l}\text { Raw materials extraction and production; } \\
\text { use and maintenance and disposal }\end{array}$ & $\begin{array}{l}\text { "area to be paved in a room of } 20 \text { feet ( } 6096 \\
\mathrm{~mm} \text { ) long and } 20 \text { feet ( } 6096 \mathrm{~mm} \text { ) wide built } \\
\text { in a typical single storey school building of } 80 \\
\text { feet ( } 24,384 \mathrm{~mm} \text { ) long and } 20 \text { feet ( } 6096 \mathrm{~mm} \text { ) } \\
\text { wide, for } 50 \text { years" }\end{array}$ \\
\hline
\end{tabular}


Table A1.1 Literature review (continued)

\begin{tabular}{|c|c|c|c|c|c|}
\hline Reference & Coverings & Environmental impact categories & Evaluation method & Scope/limits & Functional Unit \\
\hline Traverso et al., 2010 & $\begin{array}{l}\text { Sicilian marble } \\
\text { (marble chips floor } \\
\text { tile and marble } \\
\text { slabs) }\end{array}$ & $\begin{array}{l}\mathrm{GWP} \text { ( } \mathrm{kg} \mathrm{CO}_{2} \text { eq.) } \\
\mathrm{EP}\left(\mathrm{kg} \mathrm{PO}_{4}{ }^{3-} \text { eq.) }\right. \\
\mathrm{AP} \text { ( } \mathrm{kg} \mathrm{SO}_{2} \text { eq.) } \\
\mathrm{POCP} \text { ( } \mathrm{kg} \text { ethylene eq.) } \\
\text { Embodied energy (MJ) }\end{array}$ & $\begin{array}{l}\text { CML-IA-Aug.2007 (9) } \\
\text { Embodied energy: Cole and } \\
\text { Rousseau, } 1992(10)\end{array}$ & Extraction and production & $1 \mathrm{~m}^{3}$ of marble \\
\hline Bovea et al., 2010 & Ceramic tiles & $\begin{array}{l}\text { ADP: kg Sb eq. } \\
\text { AP: kg SO}{ }_{2} \text { eq. } \\
\text { EP: kg PO-3}{ }_{4} \text { eq. } \\
\text { GWP: } \mathrm{kg} \mathrm{CO}_{2} \text { eq. } \\
\text { ODP: kg R11 eq. } \\
\text { POCP: } \mathrm{kg} \mathrm{C}_{2} \mathrm{H}_{4} \text { eq. } \\
\text { Noise dBA }\end{array}$ & CML 2001 (Guinée 2002) (7) & $\begin{array}{l}\text { Extraction of red clay and glaze raw } \\
\text { materials, transport, production of the } \\
\text { tiles and glazes, and delivery to customer. }\end{array}$ & $\begin{array}{l}1 \mathrm{~m}^{2} \text { of manufactured and classified ceramic } \\
\text { tile, ready for sale }\end{array}$ \\
\hline $\begin{array}{l}\text { Benveniste et al., } \\
2011\end{array}$ & Ceramic tiles & $\begin{array}{l}\text { ADP: } \mathrm{kg} \mathrm{Sb} \text { eq. } \\
\mathrm{AP}: \mathrm{kg} \mathrm{SO}_{2} \text { eq. } \\
\mathrm{EP}: \mathrm{kg} \mathrm{PO}^{-3}{ }_{4} \text { eq. } \\
\mathrm{GWP}: \mathrm{kg} \mathrm{CO}_{2} \text { eq. } \\
\mathrm{ODP}: \mathrm{kg} \mathrm{R} 11 \text { eq. } \\
\text { POCP: } \mathrm{kg} \mathrm{C}_{2} \mathrm{H}_{4} \text { eq. } \\
\text { Primary energy consumption: MJ } \\
\text { water consumption: } \mathrm{m}^{3}\end{array}$ & CML 2001 (Guinée 2002) (7) & $\begin{array}{l}\text { Cradle to grave, including fixing material } \\
\text { and } 3 \text { scenarios of use: residential, } \\
\text { commercial and sanitary }\end{array}$ & $\begin{array}{l}\text { "Covering } 1 \mathrm{~m}^{2} \text { of surface (wall or floor) of a } \\
\text { building with ceramic tiles for } 50 \text { years } \\
\text { considering a residential, commercial or } \\
\text { sanitary use". }\end{array}$ \\
\hline $\begin{array}{l}\text { Ibañez-Forés et al., } \\
2011\end{array}$ & $\begin{array}{l}\text { Glazed stoneware } \\
\text { tile }\end{array}$ & $\begin{array}{l}\text { ADP: } \mathrm{kg} \mathrm{Sb} \text { eq. } \\
\mathrm{AP}: \mathrm{kg} \mathrm{SO}_{2} \text { eq. } \\
\mathrm{EP}: \mathrm{kg} \mathrm{PO}^{-3} \text { eq. }\end{array}$ & CML 2001 (Guinée 2002) (7) & Cradle to grave except use stage & $1 \mathrm{~m}^{2}$ of ceramic tile over a period of 20 years \\
\hline
\end{tabular}




\begin{tabular}{|c|c|c|c|c|c|}
\hline & & $\begin{array}{l}\text { GWP: } \mathrm{kg} \mathrm{CO} \mathrm{CO}_{2} \text { eq. } \\
\text { ODP: kg R11 eq. } \\
\text { POCP: } \mathrm{kg} \mathrm{C} \mathrm{C}_{2} \text { eq. } \\
\text { Human toxicity kg1.4 DB eq. }\end{array}$ & & & \\
\hline Gazi et al., 2012 & Marble & $\mathrm{CO}_{2}$ eq. & $\begin{array}{l}\mathrm{CO}_{2} \text { equivalent based on energy } \\
\text { consumption }\end{array}$ & Cradle to gate & $1 \mathrm{~m}^{3}$ of marble \\
\hline $\begin{array}{l}\text { Minne and } \\
\text { Crittenden, } 2015\end{array}$ & $\begin{array}{l}\text { Carpet of nylon } 6.6 \\
\text { Hardwood } \\
\text { Linoleum } \\
\text { Vinyl } \\
\text { Ceramic }\end{array}$ & $\begin{array}{l}\text { Climate Change: } \mathrm{kg} \mathrm{CO}_{2} \text { eq. } \\
\text { Fossil depletion ( } \mathrm{kg} \text { oil eq.) } \\
\text { POCP ( } \mathrm{kg} \text { NMVOC) } \\
\text { Particulate matter formation ( } \mathrm{kg} \\
\mathrm{PM}_{10} \text { eq.) } \\
\text { Water depletion ( } \mathrm{m}^{3} \text { ) } \\
\text { Fresh water eutrophication (kg P } \\
\text { eq.) } \\
\text { Land occupation }\left(\mathrm{m}^{2} \mathrm{a}\right) \\
\text { Human toxicity } \mathrm{kg} 1.4 \mathrm{DB} \text { eq. }\end{array}$ & $\begin{array}{l}\text { ReCiPe mindpoint and endpoint } \\
\text { hierarchist }\end{array}$ & $\begin{array}{l}\text { Raw materials, manufacturing, installation, } \\
\text { use (several scenarios) and end-of-life }\end{array}$ & $\begin{array}{l}1 \mathrm{~m}^{2} \text { of flooring in residential scenario for } 61 \\
\text { years }\end{array}$ \\
\hline
\end{tabular}

Table A1.1 Literature review (continued)

\begin{tabular}{|c|c|c|c|c|c|}
\hline Reference & Coverings & Environmental impact categories & Evaluation method & Scope/limits & Functional Unit \\
\hline Islam et al. 2015 & $\begin{array}{l}\text { Carpet } \\
\text { Plywood } \\
\text { Concrete slabs } \\
\text { Ceramic tiles }\end{array}$ & $\begin{array}{l}\text { Australian Impact Method with } \\
\text { Normalization }\end{array}$ & $\begin{array}{l}\text { Greenhouse gases ( } \mathrm{tCO}_{2} \text {-eq); } \\
\text { CED (GJ); Solid waste (tonne); }\end{array}$ & $\begin{array}{l}\text { Construction, operation 8heating and } \\
\text { cooling energy), maintenance and final } \\
\text { disposal. It considers all the constructive } \\
\text { solution system. Different types of floor } \\
\text { depending on the room. }\end{array}$ & House over its 50-year lifetime \\
\hline Almeida et al., 2016 & $\begin{array}{l}\text { Ceramic tiles (glazed } \\
\text { tiles and unglazed) }\end{array}$ & $\begin{array}{l}\text { ADPE: kg Sb eq. } \\
\text { ADPF: } \mathrm{MJ} \\
\text { AP: } \mathrm{kg} \mathrm{SO}_{2} \text { eq. }\end{array}$ & $\begin{array}{l}\text { CML2001 (ADP-elements; ADP } \\
\text { - fossil; AP; EP; GWP; ODP; } \\
\text { POCP) (11) }\end{array}$ & Cradle to grave & $1 \mathrm{~m}^{2}$ of ceramic tile with a lifespan of 50 years \\
\hline
\end{tabular}




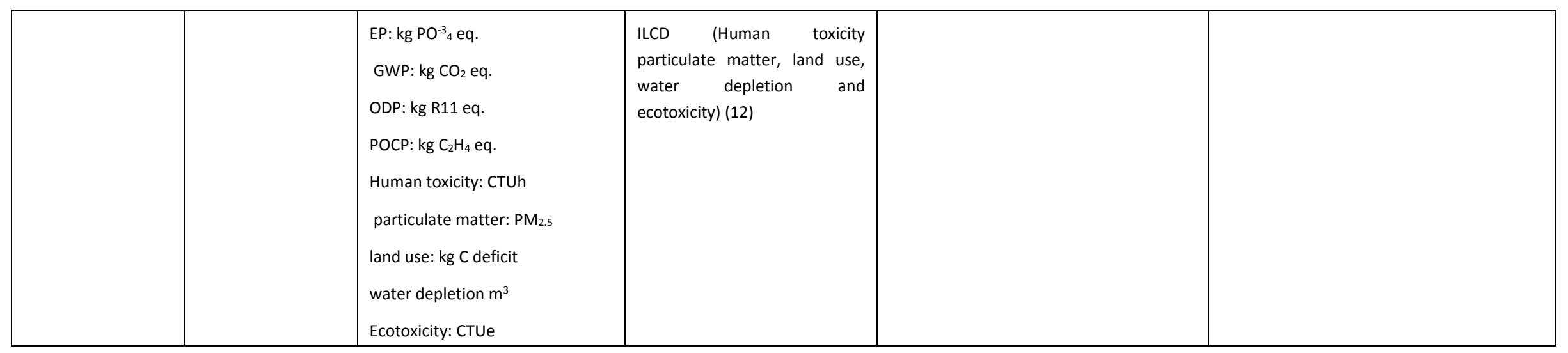




\begin{tabular}{|c|c|c|c|c|c|}
\hline $\begin{array}{l}\text { Ruschi Mendes } \\
\text { Saade et al. } 2014\end{array}$ & Ceramic tiles & $\begin{array}{l}\text { Embodied energy }(\mathrm{MJ}) ; \text { embodied } \\
\mathrm{CO}_{2} \mathrm{e} ; \\
\text { blue water footprint }\left(\mathrm{m}^{3}\right) ; \\
\text { non-renewable minerals }(\mathrm{kg}) ; \\
\text { volatile organic compound } \\
\text { emissions ( } \mathrm{kg})\end{array}$ & Method unknown & Cradle to gate & $1 \mathrm{~m}^{2}$ of gross floor area (GFA) \\
\hline Reza et al., 2011 & $\begin{array}{l}\text { Three block joisted } \\
\text { flooring system: } \\
\text { concrete, clay and } \\
\text { polystyrene blocks }\end{array}$ & $\begin{array}{l}\text { Resources depletion } \\
\text { Wastes and emissions } \\
\text { Waste management } \\
\text { Climate change } \\
\text { Environmental risk } \\
\text { Embodied energy } \\
\text { Energy loss }\end{array}$ & Method unknown & Cradle to grave & $\begin{array}{l}\text { Construction on } 1 \mathrm{~m}^{2} \text { horizontal floor area } \\
\text { over the design period of } 30 \text { years }\end{array}$ \\
\hline Hesser et al., 2017 & $\begin{array}{l}\text { Multilayer wood } \\
\text { parquet }\end{array}$ & $\begin{array}{l}\text { Non-renewable energy use } \\
\text { (MJ) } \\
\text { Global warming potential (kg } \\
\mathrm{CO}_{2} \text { eq.) }\end{array}$ & $\begin{array}{l}\text { from datasets mainly for } \\
\text { transportation and electricity } \\
\text { from GEMIS database (13) }\end{array}$ & Cradle to grave & covering of $1 \mathrm{~m}^{2}$ of ground \\
\hline Tikul, 2014 & $\begin{array}{l}\text { Ceramic tile } \\
\text { Marble tiles } \\
\text { Untreated solid } \\
\text { parquet }\end{array}$ & $\begin{array}{l}\text { Global warming } \\
\text { Acidification } \\
\text { Eutrophication } \\
\text { Ozone depletion }\end{array}$ & Eco-indicator 95 & Cradle to grave & $1 \mathrm{~m}^{2}$ of flooring materials \\
\hline
\end{tabular}


Table A1.1 Literature review (continued)

\begin{tabular}{|c|c|c|c|c|c|}
\hline Reference & Coverings & Environmental impact categories & Evaluation method & Scope/limits & Functional Unit \\
\hline $\begin{array}{l}\text { Tikul and Srichandr, } \\
2010\end{array}$ & Ceramic tile & $\begin{array}{l}\text { Global warming }\left(\mathrm{kg} \mathrm{CO}_{2}\right) \\
\text { Ozone depletion }(\mathrm{kg} \mathrm{CFC11)} \\
\text { Acidification }\left(\mathrm{kg} \mathrm{SO}_{2}\right) \\
\text { Eutrophication }\left(\mathrm{kg} \mathrm{NO}_{3}\right) \\
\text { Photochemical smog }(\mathrm{kg} \text { ethene) } \\
\text { Human toxicity air }\left(\mathrm{m}^{3}\right) \\
\text { Human toxicity water }\left(\mathrm{m}^{3}\right) \\
\text { Human toxicity soil }\left(\mathrm{m}^{3}\right) \\
\text { Ecotoxicity water chronic }\left(\mathrm{m}^{3}\right) \\
\text { Ecotoxicity water acute }\left(\mathrm{m}^{3}\right) \\
\text { Ecotoxicity soil chronic }\left(\mathrm{m}^{3}\right)\end{array}$ & $\begin{array}{l}\text { EDIP methodology and Eco- } \\
\text { indicator } 99 \text { methodology }\end{array}$ & Cradle to gate & $\begin{array}{l}\text { one megagram }(\mathrm{Mg}) \text { of double-fired glazed } \\
\text { plain white and pink ceramic tiles, size } 98 \mathrm{~mm} \\
\times 98 \mathrm{~mm} \times 5 \mathrm{~mm} \text { thick }\end{array}$ \\
\hline Pini et al., 2016 & $\begin{array}{l}\text { Thin ceramic } \\
\text { stoneware slab } \\
\text { reinforced with a } \\
\text { fibreglass backing }\end{array}$ & $\begin{array}{l}\text { Human health; Ecosystem quality; } \\
\text { Climate change; Resources; Single } \\
\text { score (Pt) }\end{array}$ & IMPACT 2002+ & $\begin{array}{l}\text { Raw materials supply, transport of raw } \\
\text { materials, manufacturing, distribution and } \\
\text { end of life }\end{array}$ & $\begin{array}{l}1 \mathrm{~m}^{2} \text { of a black, large, thin ceramic tile } \\
(3.5 \mathrm{~mm}) \text { reinforced } \\
\text { with fibreglass backing }\end{array}$ \\
\hline $\begin{array}{l}\text { Ros-Dosdá et al., } \\
2018\end{array}$ & $\begin{array}{l}\text { Porcelain stoneware } \\
\text { tile (15 varieties) }\end{array}$ & $\begin{array}{l}\text { ADPE: kg Sb eq. } \\
\text { ADPF: } M J \\
\text { AP: } \mathrm{kg} \mathrm{SO}_{2} \text { eq. } \\
\text { EP: } \mathrm{kg} \mathrm{PO}^{-3} 4 \text { eq. } \\
\text { GWP: } \mathrm{kg} \mathrm{CO}_{2} \text { eq. } \\
\text { ODP: kg R11 eq. } \\
\text { POCP: } \mathrm{kg} \mathrm{C}_{2} \mathrm{H}_{4} \text { eq. }\end{array}$ & CML2001 (11) & Cradle to grave & $\begin{array}{l}\text { Covering } 1 \mathrm{~m}^{2} \text { of household floor surface for } \\
50 \text { years with different varieties of porcelain } \\
\text { stoneware tile. }\end{array}$ \\
\hline
\end{tabular}




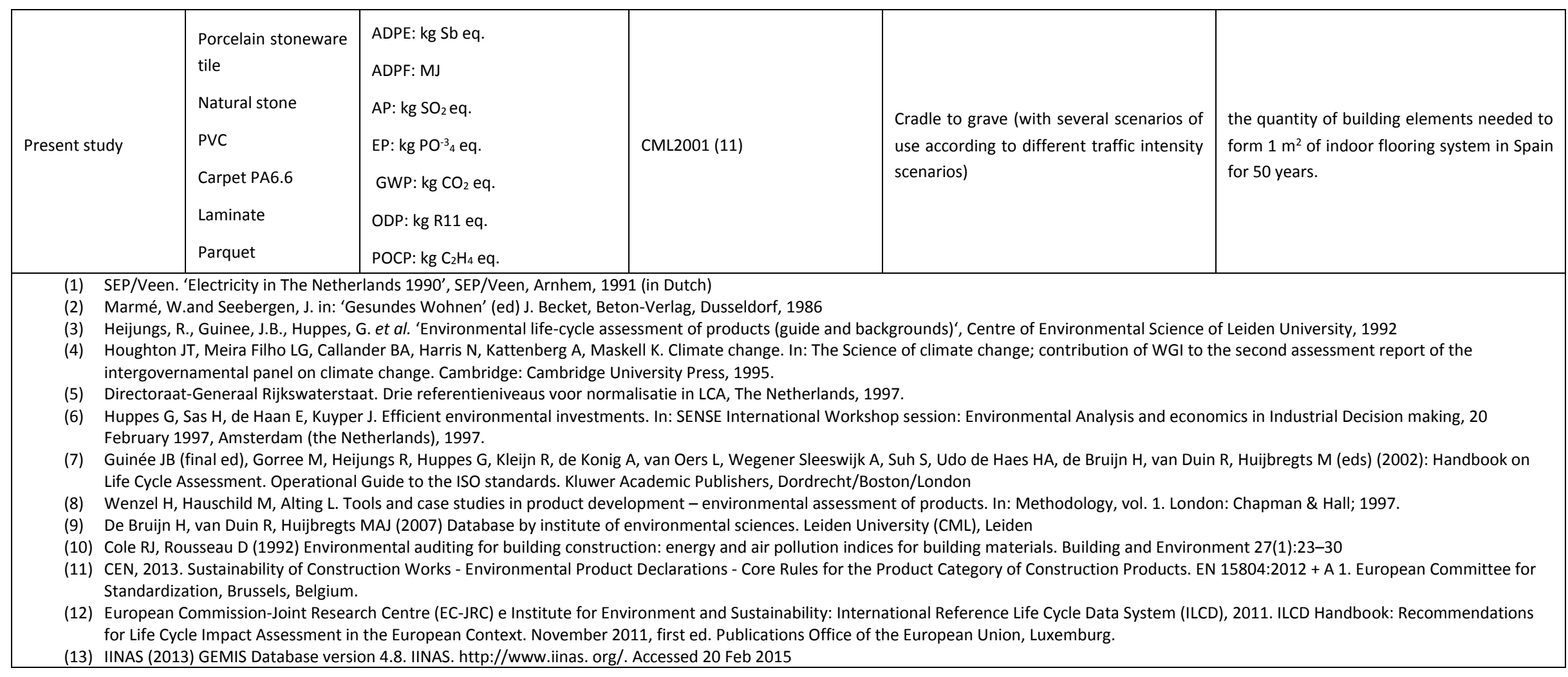




\section{References}

Abeysundara, U.G.Y., Babel, S., Piantanakulchai, M., 2009. A matrix for selecting sustainable floor coverings for buildings in Sri Lanka. J. Clean. Prod. 17, 231-238. https://doi.org/https://doi.org/10.1016/j.jclepro.2008.05.002

Almeida, M.I., Dias, A.C., Demertzi, M., Arroja, L., 2016. Environmental profile of ceramic tiles and their potential for improvement. J. Clean. Prod. 131, 583-593. https://doi.org/10.1016/j.jclepro.2016.04.131

Benveniste, G., Gazulla, C., Fullana, P., Celades, I., Ros, T., Moliner, R., Zaera, V., Godes, B., 2010. Sectoral Life cycle assessment of ceramic tile, in: XI Global Forum of Ceramic Tile. Castellón, Spain.

Bovea, M.D., Díaz-Albo, E., Gallardo, A., Colomer, F.J., Serrano, J., 2010. Environmental performance of ceramic tiles: Improvement proposals. Mater. Des. 31, 35-41. https://doi.org/10.1016/j.matdes.2009.07.021

Gazi, A., Skevis, G., Founti, M.A., 2012. Energy efficiency and environmental assessment of a typical marble quarry and processing plant. J. Clean. Prod. 32, 10-21. https://doi.org/https://doi.org/10.1016/j.jclepro.2012.03.007

Günther, A., Langowski, H.-C., 1997. Life cycle assessment study on resilient floor coverings. Int. J. Life Cycle Assess. 2, 73-80. https://doi.org/https://doi.org/10.1007/BF02978763

Hesser, F., Wohner, B., Meints, T., Stern, T., Windsperger, A., 2017. Integration of LCA in R\&D by applying the concept of payback period: case study of a modified multilayer wood parquet. Int. J. Life Cycle Assess. 22, 307-316. https://doi.org/https://doi.org/10.1007/s11367-016-1173y

Ibáñez-Forés, V., Bovea, M.-D., Simó, A., 2011. Life cycle assessment of ceramic tiles. Environmental and statistical analysis. Int. J. Life Cycle Assess. 16, 916-928. https://doi.org/10.1007/s11367-011-0322-6

Islam, H., Jollands, M., Setunge, S., Haque, N., Bhuiyan, M.A., 2015. Life cycle assessment and life cycle cost implications for roofing and floor designs in residential buildings. Energy Build. 104, 250-263. https://doi.org/10.1016/j.enbuild.2015.07.017

Jönsson, Å., Tillman, A.-M., Svensson, T., 1997. Life cycle assessment of flooring materials: case study. Build. Environ. 32, 245-255.

Minne, E., Crittenden, J.C., 2015. Impact of maintenance on life cycle impact and cost assessment for residential flooring options. Int. J. Life Cycle Assess. 20, 36-45. https://doi.org/10.1007/s11367-014-0809-z

Nebel, B., Zimmer, B., Wegener, G., 2006. Life cycle assessment of wood floor coverings-a representative study for the german flooring industry. Int. J. life cycle Assess. 11, 172-182. https://doi.org/https://doi.org/10.1065/lca2004.10.187

Nicoletti, G.M., Notarnicola, B., Tassielli, G., 2002. Comparative Life Cycle Assessment of flooring materials: ceramic versus marble tiles. J. Clean. Prod. 10, 283-296. https://doi.org/10.1016/S0959-6526(01)00028-2 
Pini, M., Ferrari, A.M., Gamberini, R., Neri, P., Rimini, B., 2014. Life cycle assessment of a large, thin ceramic tile with advantageous technological properties. Int. J. Life Cycle Assess. 19, 15671580. https://doi.org/10.1007/s11367-014-0764-8

Potting, J., Blok, K., 1995. Life-cycle assessment of four types of floor covering. J. Clean. Prod. 3, 201-213. https://doi.org/https://doi.org/10.1016/0959-6526(95)00082-8

Reza, B., Sadiq, R., Hewage, K., 2011. Sustainability assessment of flooring systems in the city of Tehran: An AHP-based life cycle analysis. Constr. Build. Mater. 25, 2053-2066. https://doi.org/https://doi.org/10.1016/j.conbuildmat.2010.11.041

Ros-Dosdá, T., Celades, I., Monfort, E., Fullana-i-Palmer, P., 2018. Environmental profile of Spanish porcelain stoneware tiles. Int. J. Life Cycle Assess. 23, 1562-1580. https://doi.org/10.1007/s11367-017-1377-9

Ruschi Mendes Saade, M., G. da Silva, M., Gomes, V., Gumez Franco, H., Schwamback, D., Lavor, B., 2014. Material eco-efficiency indicators for Brazilian buildings. Smart Sustain. Built Environ. 3, 54-71. https://doi.org/10.1108/SASBE-04-2013-0024

Tikul, N., 2014. Assessing environmental impact of small and medium ceramic tile manufacturing enterprises in Thailand. J. Manuf. Syst. 33, 1-6. https://doi.org/https://doi.org/10.1016/j.jmsy.2013.12.002

Tikul, N., Srichandr, P., 2010. Assessing the environmental impact of ceramic tile production in Thailand. J. Ceram. Soc. Japan 118, 887-894. https://doi.org/10.2109/jcersj2.118.887

Traverso, M., Rizzo, G., Finkbeiner, M., 2010. Environmental performance of building materials: life cycle assessment of a typical Sicilian marble. Int. J. Life Cycle Assess. 15, 104. 


\section{Appendix 2:}

\section{Use of EPDs as information source}

Using the methodology set out in Section 2.4.1. of the paper, several EPDs were selected and processed to obtain information on environmental impacts relating to the product stage (life cycle modules A1-A3) and other additional information relative to the description of subsequent life cycle stages.

A total of 149 EPDs of indoor floor coverings registered in the following programs were consulted: the International EPD® System; Institut Bauen und Umwelt e. V. (IBU-EPD); DAPcons; GlobalEPD; Inies and EPDnorge.

Table A2.1 details the EPDs consulted in this study. 
1 Table A2.1 List of EDPs evaluated in this study

\begin{tabular}{|c|c|c|c|c|c|c|c|c|c|c|c|c|}
\hline Coverings & $\begin{array}{c}\text { EPD } \\
\text { program }\end{array}$ & Database & Country & $\begin{array}{c}\text { Year of } \\
\text { publication }\end{array}$ & Year of data & FU/DU & $\begin{array}{l}\text { Interpretation } \\
\text { of results }\end{array}$ & $\begin{array}{l}\text { Description of the } \\
\text { product }\end{array}$ & $\begin{array}{c}\text { PCR } \\
\text { identification }\end{array}$ & $\begin{array}{l}\text { List of materials } \\
\text { to be declared }\end{array}$ & $\begin{array}{l}\text { Information of } \\
\text { stages not } \\
\text { considered }\end{array}$ & $\begin{array}{l}\text { Cut-off } \\
\text { rules }\end{array}$ \\
\hline LAM1 & IBU & GaBi 2017 & $\mathrm{BE}, \mathrm{RU}$ & 2017 & 2015 & $1 \mathrm{~m}^{2}$ & Yes & Yes & Yes & Yes & No & $1 \% / 5 \%$ \\
\hline LAM2 & IBU & $\mathrm{GaBi}$ & $\mathrm{DE}$ & 2016 & 2014 & $1 \mathrm{~m}^{2}$ & No & Yes & Yes & Yes & No & No (1) \\
\hline LAM3 & IBU & $\mathrm{GaBi}$ & EU & 2015 & 2013 & $1 \mathrm{~m}^{2}$ & No & Yes & Yes & Yes & No & No (1) \\
\hline LAM4 & IBU & Ecoinvent v.2.2 & $\mathrm{DE}$ & 2013 & 2012 & $1 \mathrm{~m}^{2}$ & Yes & Yes & Yes & No & No & $<5 \%$ Mass \\
\hline LAM5 & IBU & $\mathrm{GaBi}$ & IT & 2016 & 2014 & $1 \mathrm{~m}^{2}$ & No & Yes & Yes & Yes & No & No (1) \\
\hline WD1 & INIES & n.d. & FR & 2015 & n.d. & $1 \mathrm{~m}^{2}$ & No & Yes & Yes & No & Yes & No \\
\hline WD2 & INIES & n.d. & FR & 2015 & n.d. & $1 \mathrm{~m}^{2}$ & No & Yes & Yes & No & Yes & No \\
\hline WD3* & IBU & GaBi 6.412 & $\mathrm{DE}$ & 2015 & 2009 & $1 \mathrm{~m}^{2}$ & Yes & Yes & Yes & - & No & $1 \% / 5 \%$ \\
\hline WD4-5 & Int EPD Sys & $\mathrm{GaBi}$ & $\mathrm{AU}$ sector & 2017 & 2015_2016 & $1 \mathrm{~m} 2$ & No & Yes & Yes & No & Yes & No \\
\hline PVC1 & $\mathrm{IBU}$ & n.d. & EU & 2013 & 2011 & $1 \mathrm{~m}^{2}$ & No & Yes & Yes & Yes & No & No (1) \\
\hline PVC2 & $\mathrm{IBU}$ & GaBi 6 & $\mathrm{CH}$ & 2013 & 2010 & $1 \mathrm{~m}^{2}$ & Yes & Yes & Yes & Yes & No & $1 \% / 5 \%$ \\
\hline PVC3 & IBU & n.d. & EU & 2013 & 2011 & $1 \mathrm{~m}^{2}$ & No & Yes & Yes & Yes & No & No (1) \\
\hline PVC4 & IBU & n.d. & EU & 2013 & 2011 & $1 \mathrm{~m}^{2}$ & No & Yes & Yes & Yes & No & No (1) \\
\hline PVC5 & IBU & n.d. & EU & 2013 & 2011 & $1 \mathrm{~m}^{2}$ & No & Yes & Yes & Yes & No & No (1) \\
\hline PVC6 & $\mathrm{IBU}$ & n.d. & EU & 2013 & 2011 & $1 \mathrm{~m}^{2}$ & No & Yes & Yes & Yes & No & No (1) \\
\hline PVC7 & $\mathrm{IBU}$ & n.d. & EU & 2013 & 2011 & $1 \mathrm{~m}^{2}$ & No & Yes & Yes & Yes & No & No (1) \\
\hline PVC8 & $\mathrm{IBU}$ & n.d. & EU & 2013 & 2011 & $1 \mathrm{~m}^{2}$ & No & Yes & Yes & Yes & No & No (1) \\
\hline PVC9 & $\mathrm{IBU}$ & n.d. & EU & 2013 & 2011 & $1 \mathrm{~m}^{2}$ & No & Yes & Yes & Yes & No & No (1) \\
\hline PVC10 & Int EPD Sys & Ecoinvent v3.1 & $\mathrm{AU}, \mathrm{NZ}$ & 2017 & 2014 & $1 \mathrm{~m}^{2}$ & Yes & Yes & Yes & Yes & No & $1 \% / 5 \%$ \\
\hline PVC11 & Int EPD Sys & Ecoinvent v3.1 & $\mathrm{KR}$ & 2016 & $2014 / 2015$ & $1 \mathrm{~m}^{2}$ & Yes & Yes & Yes & Yes & No & $<5 \%$ \\
\hline PVC12 & Int EPD Sys & Ecoinvent v3.1 & $\mathrm{CH}, \mathrm{KR}, \mathrm{TW}$ & 2016 & $2011 / 2012$ & $1 \mathrm{~m}^{2}$ & Yes & Yes & Yes & Yes & No & $<5 \%$ \\
\hline PVC13 & Int EPD Sys & Ecoinvent v3.1 & KR & 2016 & $2014 / 2015$ & $1 \mathrm{~m}^{2}$ & Yes & Yes & Yes & Yes & No & $<5 \%$ \\
\hline
\end{tabular}




\begin{tabular}{|c|c|c|c|c|c|c|c|c|c|c|c|c|}
\hline Coverings & $\begin{array}{c}\text { EPD } \\
\text { program }\end{array}$ & Database & Country & $\begin{array}{c}\text { Year of } \\
\text { publication }\end{array}$ & Year of data & FU/DU & $\begin{array}{l}\text { Interpretation } \\
\text { of results }\end{array}$ & $\begin{array}{l}\text { Description of the } \\
\text { product }\end{array}$ & $\begin{array}{c}\mathrm{PCR} \\
\text { identification }\end{array}$ & $\begin{array}{l}\text { List of materials } \\
\text { to be declared }\end{array}$ & $\begin{array}{l}\text { Information of } \\
\text { stages not } \\
\text { considered }\end{array}$ & $\begin{array}{l}\text { Cut-off } \\
\text { rules }\end{array}$ \\
\hline PVC14 & Int EPD Sys & Ecoinvent v3.1 & $\mathrm{CH}, \mathrm{KR}, \mathrm{TW}$ & 2016 & $2011 / 2012$ & $1 \mathrm{~m}^{2}$ & Yes & Yes & Yes & Yes & No & $<5 \%$ \\
\hline NS1 & IBU & n.d. & EU & 2014 & 2009/2011 & $1 t^{*}$ & No & Yes & Yes & No & No & No (1) \\
\hline NS2 & EPDNorge & Ecoinvent v3.2 & NO & 2018 & 2017 & $1 t^{*}$ & No & Yes & Yes & Yes & Yes & $<1 \%$ \\
\hline PST1 & IBU & GaBi 6/ELCD 3.2 & IT & 2016 & 2014 & $1 \mathrm{~m}^{2}$ & Yes & Yes & Yes & Yes & Yes & $1 \% / 5 \%$ \\
\hline PST2 & IBU & GaBi 6/ELCD 3.2 & IT & 2016 & 2014 & $1 \mathrm{~m}^{2}$ & Yes & Yes & Yes & Yes & Yes & $1 \% / 5 \%$ \\
\hline PST3 & DAPcons & ELCD/DAPcons DB & ES & 2017 & 2016 & $1 \mathrm{~m}^{2}$ & No & Yes & Yes & Yes & Yes & $<5 \%$ \\
\hline PST4 & DAPcons & ELCD/DAPcons DB & ES & 2017 & $2016 / 2017$ & $1 \mathrm{~m}^{2}$ & No & Yes & Yes & No & Yes & $<5 \%$ \\
\hline PST5 & DAPcons & ELCD/DAPcons DB & ES & 2016 & 2015 & $1 \mathrm{~m}^{2}$ & No & Yes & Yes & No & Yes & $<5 \%$ \\
\hline PST6 & DAPcons & ELCD/DAPcons DB & ES & 2017 & $2016 / 2017$ & $1 \mathrm{~m}^{2}$ & No & Yes & Yes & No & Yes & $<5 \%$ \\
\hline PST7 & DAPcons & ELCD/DAPcons DB & ES & 2016 & 2015 & $1 \mathrm{~m}^{2}$ & No & Yes & Yes & No & Yes & $<5 \%$ \\
\hline РST8 & DAPcons & ELCD/DAPcons DB & ES & 2017 & 2015 & $1 \mathrm{~m}^{2}$ & No & Yes & Yes & No & Yes & $<5 \%$ \\
\hline РST9 & DAPcons & ELCD/DAPcons DB & ES & 2018 & 2016 & $1 \mathrm{~m}^{2}$ & No & Yes & Yes & No & Yes & $<5 \%$ \\
\hline PST10 & GlobalEPD & GaBi 4.4 & ES & 2013 & n.d. & $1 \mathrm{~m}^{2}$ & No & Yes & Yes & No & Yes & No (1) \\
\hline PST11 & GlobalEPD & GaBi 4.4 & ES & 2013 & 2010 & $1 \mathrm{~m}^{2}$ & No & Yes & Yes & Yes & Yes & No (1) \\
\hline PST12 & GlobalEPD & GaBi 4.4 & ES & 2013 & n.d. & $1 \mathrm{~m}^{2}$ & No & Yes & Yes & Yes & Yes & No (1) \\
\hline PST13 & GlobalEPD & GaBi 4.4 & ES & 2013 & $2011 / 2012$ & $1 \mathrm{~m}^{2}$ & No & Yes & Yes & Yes & Yes & No (1) \\
\hline PST14 & GlobalEPD & GaBi 4.4 & ES & 2015 & 2013 & $1 \mathrm{~m}^{2}$ & No & Yes & Yes & Yes & Yes & No (1) \\
\hline PST15 & GlobalEPD & GaBi 4.4 & ES & 2013 & 2011 & $1 \mathrm{~m}^{2}$ & No & Yes & Yes & Yes & Yes & No (1) \\
\hline PST16 & GlobalEPD & GaBi 4.4 & ES & 2016 & 2014 & $1 \mathrm{~m}^{2}$ & No & Yes & Yes & Yes & Yes & No (1) \\
\hline PST17 & GlobalEPD & GaBi 4.4 & ES & 2016 & 2014 & $1 \mathrm{~m}^{2}$ & No & Yes & Yes & Yes & Yes & No (1) \\
\hline PST18 & IBU & GaBi 7 (SP30) & DE sector & 2016 & 2009/2014 & $1 \mathrm{~m}^{2}$ & Yes & Yes & Yes & No & Yes & $<1 \%$ \\
\hline PST19 & IBU & GaBi/ELCD & IT sector & 2016 & 2014 & $1 \mathrm{~m}^{2}$ & Yes & Yes & Yes & No & Yes & $0 \%$ \\
\hline PST20 & IBU & GaBi 2016 & IT & 2017 & n.d. & $1 \mathrm{~m}^{2}$ & No & Yes & Yes & No & Yes & No (1) \\
\hline TEX1-21 & IBU & n.d. & DK & 2013-2018 & n.d. & $1 \mathrm{~m}^{2}$ & No & Yes & Yes & No & Yes & No (1) \\
\hline
\end{tabular}




\begin{tabular}{|c|c|c|c|c|c|c|c|c|c|c|c|c|}
\hline Coverings & $\begin{array}{c}\text { EPD } \\
\text { program }\end{array}$ & Database & Country & $\begin{array}{c}\text { Year of } \\
\text { publication }\end{array}$ & Year of data & FU/DU & $\begin{array}{l}\text { Interpretation } \\
\text { of results }\end{array}$ & $\begin{array}{l}\text { Description of the } \\
\text { product }\end{array}$ & $\begin{array}{c}\text { PCR } \\
\text { identification }\end{array}$ & $\begin{array}{l}\text { List of materials } \\
\text { to be declared }\end{array}$ & $\begin{array}{l}\text { Information of } \\
\text { stages not } \\
\text { considered }\end{array}$ & $\begin{array}{l}\text { Cut-off } \\
\text { rules }\end{array}$ \\
\hline TEX22-26 & IBU & $\mathrm{GaBi}$ & EU & $2015-2016$ & n.d. & $1 \mathrm{~m}^{2}$ & No & Yes & Yes & No & Yes & No (1) \\
\hline TEX27-54 & IBU & n.d. & $\mathrm{NL}$ & $2013-2018$ & n.d. & $1 \mathrm{~m}^{2}$ & No & Yes & Yes & No & Yes & No (1) \\
\hline TEX55-58 & $\mathrm{IBU}$ & n.d. & $\mathrm{DE}$ & 2014 & n.d. & $1 \mathrm{~m}^{2}$ & No & Yes & Yes & No & Yes & No (1) \\
\hline TEX59-67 & $\mathrm{IBU}$ & n.d. & UK & $2014-2018$ & n.d. & $1 \mathrm{~m}^{2}$ & No & Yes & Yes & No & Yes & No (1) \\
\hline TEX67-69 & IBU & n.d. & DK & 2014 & n.d. & $1 \mathrm{~m}^{2}$ & No & Yes & Yes & No & Yes & No (1) \\
\hline TEX70-71 & IBU & $\begin{array}{c}\text { Ecoinvent 3.3/ } \\
\text { GaBi SP33 }\end{array}$ & $\mathrm{NL}$ & 2014 & n.d. & $1 \mathrm{~m}^{2}$ & No & Yes & Yes & No & Yes & No (1) \\
\hline TEX72-75 & IBU & n.d. & $\mathrm{DE}$ & 2013-2017 & n.d. & $1 \mathrm{~m}^{2}$ & No & Yes & Yes & No & Yes & No (1) \\
\hline TEX76-84 & IBU & n.d. & $\mathrm{NL}$ & $2015-2016$ & n.d. & $1 \mathrm{~m}^{2}$ & No & Yes & Yes & No & Yes & No (1) \\
\hline TEX85-92 & IBU & n.d. & BE & $2015-2017$ & n.d. & $1 \mathrm{~m}^{2}$ & No & Yes & Yes & No & Yes & No (1) \\
\hline TEX93-102 & IBU & n.d. & $\mathrm{DE}$ & $2015-2018$ & n.d. & $1 \mathrm{~m}^{2}$ & No & Yes & Yes & No & Yes & No (1) \\
\hline TEX103 & Int EPD Sys & n.d. & US & 2018 & 2015 & $1 \mathrm{~m}^{2}$ & Yes & Yes & Yes & No & Yes & $1 \% / 5 \%$ \\
\hline $\begin{array}{l}\text { n.d.: no dec } \\
\text { (1): no decle }\end{array}$ & ed in the EPL & sidered in & & & & & & & & & & \\
\hline
\end{tabular}




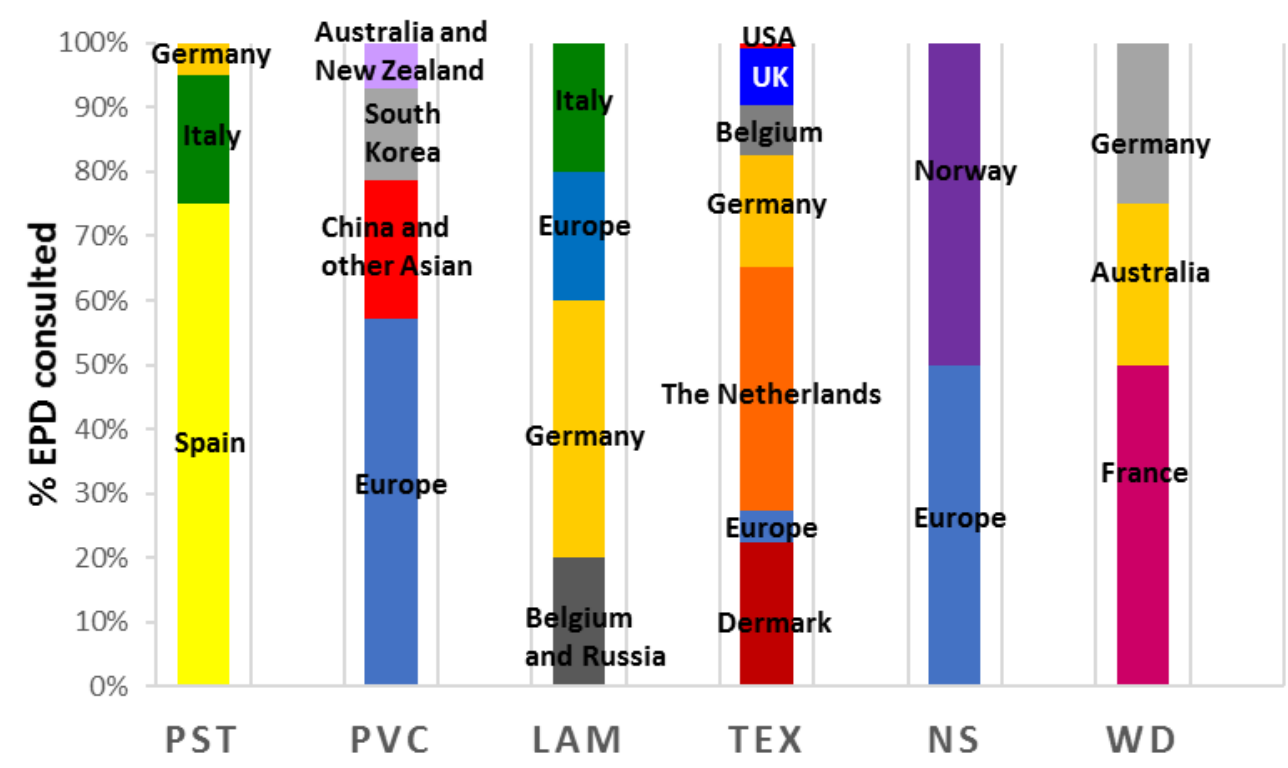

Fig. A2.1 Distribution of the consulted EPDs

Fig A.2.2 shows a box and whisker plot of the data published in the EPDs on the product stage (A1-A3), which includes raw materials extraction and transport and manufacture. At the same time, the graph provides information on the central trend, scatter, and symmetry of the study data. The boxes represent the interquartile range from the 25 th to the 75 th percentile $\left(Q_{1}\right.$ and $Q_{3}$, respectively); the cross $(X)$ represents the mean value and the line represents the value corresponding to the median $\left(Q_{2}\right)$. The whiskers represent the standard deviation and the circles the atypical values calculated from the interquartile range $\left(R I=Q_{3}-Q_{1}\right)$, the lower atypical values being the values below $f_{\min }=Q_{1}-1.5 R I$ and the upper atypical values being the values above $f_{\max }=Q_{3}+1.5 \mathrm{Rl}$

Note that the justification of the data in Fig. A.2.2 is limited to product description, the scarce interpretation included in some EPDs (only $13.6 \%$ of the consulted EPDs provided some type of information in this regard), and the literature surveyed that could provide comparable values in relation to scope, calculation methodology, and impact assessment methods. However, the study's main objective was not detailed interpretation of the values published in the EPDs or comparative analysis with own environmental data of a cradle-gate scope. Consequently, only simple comments of a statistical nature are made. 


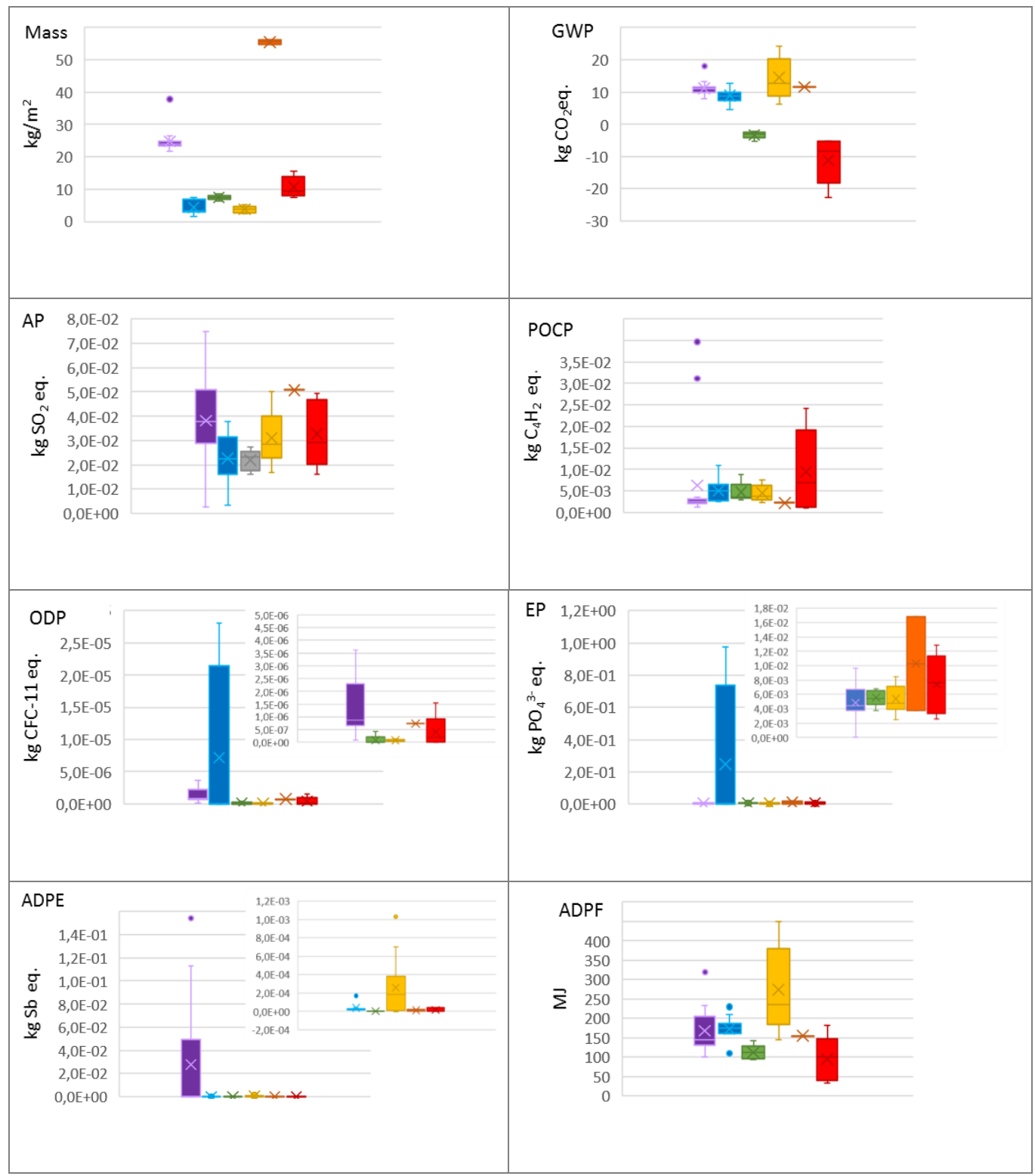

PST $\square$ PVC $\square$ LAM $\square$ TEX $\square$ NS $\square$ WD

Fig. A2.2 Environmental impacts of the studied coverings. Cradle-to-gate scope from the consulted EDPs

(Table A1)

The inorganic coverings were the heaviest, whereas the polymer coverings were the lightest. NS was by far the heaviest covering: $52.1 \mathrm{~kg} / \mathrm{m}^{2}$, with densities ranging from 2600 to $2800 \mathrm{~kg} / \mathrm{m}^{3}$, and $20-\mathrm{mm}$ thickness. This was followed by PST: $24.1 \mathrm{~kg} / \mathrm{m}^{2}$, with a density of $2300 \mathrm{~kg} / \mathrm{m}^{3}$, and $10.5-\mathrm{mm}$ average thickness. The other floor coverings weighed less than $10 \mathrm{~kg} / \mathrm{m}^{2}$.

The studied coverings exhibited similar contributions (of the same order of magnitude) in the AP, POCP, and ADPF impact categories. In the GWP impact category, the wood-based coverings (laminates and parquet) provided negative values owing to stored biogenic carbon, whereas the other coverings exhibited similar behaviours. In the other categories there was a data scatter of at least two orders of magnitude. 


\section{Appendix 3:}

\section{Normalization and Weighting}

Normalization expresses the values of each impact category with respect to a reference situation (ISO 14044:2006; Laurin et al., 2016). The applied normalization factors were taken from "CML2001 - Jan. 2016, World, year 2000 , incl biogenic carbon (global equivalents)" (Table S3.1).

Weighting is a subjective process aiming to rank the results based on the relative importance of each impact category given from factors based on value-choices (ISO 14040-44:2006; Huppes et al. 2012; Cortés-Borda et al. 2013). The weighting factors applied were those obtained by Thinkstep "LCIA Survey 2012, Global, CML 2016, incl biogenic carbon (global equivalents weighted" (Table S3.1).

Table S3.1 Weighting and normalization factors

\begin{tabular}{|c|c|c|}
\hline Environmental indicators & Weighting Factors & Normalization Factors \\
\hline GWP & 0.193 & $4.22 \mathrm{E}+13$ \\
\hline AP & 0.127 & $2.39 \mathrm{E}+11$ \\
\hline EP & 0.137 & $1.58 \mathrm{E}+11$ \\
\hline ODP & 0.129 & $2.27 \mathrm{E}+08$ \\
\hline POCP & 0.135 & $3.68 \mathrm{E}+10$ \\
\hline ADPE & 0.133 & $3.61 \mathrm{E}+08$ \\
\hline ADPF & 0.146 & $3.80 \mathrm{E}+14$ \\
\hline
\end{tabular}

The tables S3.2, table S3.3. and table S3.4 show the absolute, normalized and weighted values of the FS evaluation, respectively, considering the three use scenarios.

Table S3.2 Results of the life cycle analysis of each FS. Absolute values

\begin{tabular}{|c|c|c|c|c|c|c|c|c|}
\hline \multirow{2}{*}{\multicolumn{2}{|c|}{$\begin{array}{l}\text { Impact } \\
\text { categories }\end{array}$}} & GWP & AP & EP & ODP & РОСР & ADPE & ADPF \\
\hline & & $\begin{array}{c}\mathrm{kg} \mathrm{CO} 2 \\
\mathrm{Eq} .\end{array}$ & $\begin{array}{c}\mathrm{kg} \mathrm{SO}_{2} \\
\mathrm{Eq} .\end{array}$ & $\begin{array}{c}\mathrm{kg} \mathrm{PO}_{4}{ }^{3-} \\
\mathrm{Eq} .\end{array}$ & $\begin{array}{c}\text { kg CFC- } \\
11 \text { Eq. }\end{array}$ & $\begin{array}{c}\mathrm{kg} \mathrm{C}_{2} \mathrm{H}_{4} \\
\mathrm{Eq} .\end{array}$ & $\begin{array}{c}\mathrm{kg} \mathrm{Sb} \\
\mathrm{Eq} .\end{array}$ & MJ \\
\hline \multirow{3}{*}{ PST } & Low & 14.8 & 4.7E-02 & 7.8E-03 & 8.9E-07 & $5.2 E-03$ & 8.6E-05 & 205.6 \\
\hline & Medium & 20.1 & 5.6E-02 & 1.7E-02 & 1.0E-06 & 7.6E-03 & 8.8E-05 & 221.6 \\
\hline & High & 28.3 & 7.3E-02 & $2.8 \mathrm{E}-02$ & $1.1 \mathrm{E}-06$ & 1.1E-02 & $9.2 \mathrm{E}-05$ & 265.7 \\
\hline \multirow{3}{*}{ NS } & Low & 24.5 & $6.8 \mathrm{E}-02$ & 1.5E-02 & $7.5 \mathrm{E}-07$ & 5.1E-03 & $1.9 \mathrm{E}-05$ & 336.9 \\
\hline & Medium & 29.8 & 7.8E-02 & 2.4E-02 & 8.7E-07 & 7.5E-03 & 2.1E-05 & 353.0 \\
\hline & High & 38.1 & 9.5E-02 & $3.5 \mathrm{E}-02$ & 1.0E-06 & 1.1E-02 & $2.5 \mathrm{E}-05$ & 397.3 \\
\hline
\end{tabular}


Table S3.2 Results of the life cycle analysis of each FS. Absolute values (continued)

\begin{tabular}{|c|c|c|c|c|c|c|c|c|}
\hline \multirow{2}{*}{\multicolumn{2}{|c|}{$\begin{array}{l}\text { Impact } \\
\text { categories }\end{array}$}} & GWP & AP & EP & ODP & POCP & ADPE & ADPF \\
\hline & & $\begin{array}{c}\mathrm{kg} \mathrm{CO}_{2} \\
\mathrm{Eq} .\end{array}$ & $\begin{array}{c}\mathrm{kg} \mathrm{SO}_{2} \\
\mathrm{Eq} .\end{array}$ & $\begin{array}{c}\mathrm{kg} \mathrm{PO}_{4}{ }^{3-} \\
\mathrm{Eq} .\end{array}$ & $\begin{array}{c}\mathrm{kg} \mathrm{CFC} \\
11 \mathrm{Eq} .\end{array}$ & $\begin{array}{c}\mathrm{kg} \mathrm{C}_{2} \mathrm{H}_{4} \\
\mathrm{Eq} .\end{array}$ & $\begin{array}{c}\mathrm{kg} \mathrm{Sb} \\
\mathrm{Eq} .\end{array}$ & MJ \\
\hline \multirow{3}{*}{ PVC } & Low & 36.3 & 1.0E-01 & 1.6E-02 & $9.6 \mathrm{E}-08$ & 2.3E-02 & 9.3E-05 & 724.5 \\
\hline & Medium & 47.7 & 1.2E-01 & 3.4E-02 & 3.3E-07 & 2.8E-02 & $9.8 \mathrm{E}-05$ & 770.3 \\
\hline & High & 58.5 & $1.4 \mathrm{E}-01$ & 5.5E-02 & $6.0 \mathrm{E}-07$ & 3.3E-02 & 1.0E-04 & 793.3 \\
\hline \multirow{3}{*}{ TEX } & Low & 83.1 & $1.9 \mathrm{E}-01$ & 5.4E-02 & $6.1 \mathrm{E}-07$ & $2.5 \mathrm{E}-02$ & 7.9E-04 & 1042.0 \\
\hline & Medium & 110.6 & $2.4 \mathrm{E}-01$ & 8.5E-02 & $9.8 \mathrm{E}-07$ & 3.5E-02 & 8.0E-04 & 1232.4 \\
\hline & High & 139.1 & 3.0E-01 & 1.4E-01 & 1.7E-06 & 5.0E-02 & 8.1E-04 & 1290.3 \\
\hline \multirow{3}{*}{ LAM } & Low & 35.3 & $1.4 \mathrm{E}-01$ & 3.4E-02 & $1.2 \mathrm{E}-07$ & 2.6E-02 & $1.5 \mathrm{E}-05$ & 559.9 \\
\hline & Medium & 44.3 & $1.5 \mathrm{E}-01$ & 4.6E-02 & $2.8 \mathrm{E}-07$ & 2.9E-02 & 1.9E-05 & 605.5 \\
\hline & High & 43.4 & $1.5 \mathrm{E}-01$ & 4.6E-02 & 2.8E-07 & $2.9 \mathrm{E}-02$ & $1.8 \mathrm{E}-05$ & 594.2 \\
\hline \multirow{3}{*}{ WD } & Low & 34.2 & 9.6E-02 & 1.7E-02 & $1.5 \mathrm{E}-07$ & 5.7E-02 & 2.3E-05 & 412.1 \\
\hline & Medium & 42.3 & 1.1E-01 & 1.9E-02 & 1.6E-07 & $1.0 \mathrm{E}-01$ & 3.3E-05 & 550.2 \\
\hline & High & 73.1 & $2.0 \mathrm{E}-01$ & 3.6E-02 & 3.3E-07 & 1.6E-01 & 5.3E-05 & 926.8 \\
\hline
\end{tabular}

Table S3.3 Results of the life cycle analysis of each FS. Normalized values

\begin{tabular}{|c|c|c|c|c|c|c|c|c|}
\hline \multicolumn{2}{|c|}{$\begin{array}{l}\text { Impact } \\
\text { categories }\end{array}$} & GWP & AP & EP & ODP & РОСР & ADPE & ADPF \\
\hline \multirow{3}{*}{ PST } & Low & $3.5 \mathrm{E}-13$ & $2.0 \mathrm{E}-13$ & $5.0 \mathrm{E}-14$ & $3.9 \mathrm{E}-15$ & $1.4 \mathrm{E}-13$ & $2.4 \mathrm{E}-13$ & $5.4 \mathrm{E}-13$ \\
\hline & Medium & $4.8 \mathrm{E}-13$ & $2.4 \mathrm{E}-13$ & $1.1 \mathrm{E}-13$ & 4.4E-15 & $2.1 \mathrm{E}-13$ & $2.4 \mathrm{E}-13$ & $5.8 \mathrm{E}-13$ \\
\hline & High & 6.7E-13 & 3.0E-13 & $1.8 \mathrm{E}-13$ & 5.0E-15 & $2.9 \mathrm{E}-13$ & $2.5 \mathrm{E}-13$ & $7.0 \mathrm{E}-13$ \\
\hline \multirow{3}{*}{ NS } & Low & $5.8 \mathrm{E}-13$ & $2.9 \mathrm{E}-13$ & $9.5 \mathrm{E}-14$ & 3.3E-15 & $1.4 \mathrm{E}-13$ & $5.4 \mathrm{E}-14$ & $8.9 \mathrm{E}-13$ \\
\hline & Medium & 7.1E-13 & 3.3E-13 & $1.5 \mathrm{E}-13$ & $3.8 \mathrm{E}-15$ & $2.0 \mathrm{E}-13$ & $5.9 \mathrm{E}-14$ & $9.3 \mathrm{E}-13$ \\
\hline & High & $9.0 \mathrm{E}-13$ & 4.0E-13 & $2.2 \mathrm{E}-13$ & 4.4E-15 & $2.9 \mathrm{E}-13$ & $6.9 \mathrm{E}-14$ & 1.0E-12 \\
\hline \multirow{3}{*}{ PVC } & Low & 8.6E-13 & $4.2 \mathrm{E}-13$ & $1.0 \mathrm{E}-13$ & $4.2 \mathrm{E}-16$ & $6.3 \mathrm{E}-13$ & $2.6 \mathrm{E}-13$ & $1.9 \mathrm{E}-12$ \\
\hline & Medium & 1.1E-12 & $5.1 \mathrm{E}-13$ & $2.2 \mathrm{E}-13$ & $1.4 \mathrm{E}-15$ & 7.6E-13 & 2.7E-13 & $2.0 \mathrm{E}-12$ \\
\hline & High & $1.4 \mathrm{E}-12$ & $6.0 \mathrm{E}-13$ & $3.5 \mathrm{E}-13$ & 2.6E-15 & $9.1 \mathrm{E}-13$ & $2.8 \mathrm{E}-13$ & $2.1 \mathrm{E}-12$ \\
\hline \multirow{3}{*}{ TEX } & Low & 2.0E-12 & $7.8 \mathrm{E}-13$ & 3.4E-13 & 2.7E-15 & $6.9 \mathrm{E}-13$ & $2.2 \mathrm{E}-12$ & 2.7E-12 \\
\hline & Medium & 2.6E-12 & $1.0 \mathrm{E}-12$ & $5.4 \mathrm{E}-13$ & $4.3 \mathrm{E}-15$ & $9.5 E-13$ & 2.2E-12 & $3.2 \mathrm{E}-12$ \\
\hline & High & 3.3E-12 & 1.3E-12 & $9.0 \mathrm{E}-13$ & $7.6 \mathrm{E}-15$ & 1.3E-12 & $2.2 \mathrm{E}-12$ & $3.4 \mathrm{E}-12$ \\
\hline
\end{tabular}


Table S3.3 Results of the life cycle analysis of each FS. Normalized values (continued)

\begin{tabular}{|c|c|c|c|c|c|c|c|c|}
\hline \multicolumn{2}{|c|}{$\begin{array}{c}\text { Impact } \\
\text { categories }\end{array}$} & GWP & AP & EP & ODP & POCP & ADPE & ADPF \\
\hline \multirow{4}{*}{ LAM } & Low & $8.4 \mathrm{E}-13$ & $5.7 \mathrm{E}-13$ & $2.1 \mathrm{E}-13$ & $5.3 \mathrm{E}-16$ & $7.0 \mathrm{E}-13$ & $4.2 \mathrm{E}-14$ & $1.5 \mathrm{E}-12$ \\
\cline { 2 - 8 } & Medium & $1.0 \mathrm{E}-12$ & $6.4 \mathrm{E}-13$ & $2.9 \mathrm{E}-13$ & $1.2 \mathrm{E}-15$ & $7.9 \mathrm{E}-13$ & $5.2 \mathrm{E}-14$ & $1.6 \mathrm{E}-12$ \\
\cline { 2 - 9 } & High & $1.0 \mathrm{E}-12$ & $6.4 \mathrm{E}-13$ & $2.9 \mathrm{E}-13$ & $1.2 \mathrm{E}-15$ & $7.9 \mathrm{E}-13$ & $5.0 \mathrm{E}-14$ & $1.6 \mathrm{E}-12$ \\
\hline \multirow{4}{*}{ WD } & Low & $8.1 \mathrm{E}-13$ & $4.0 \mathrm{E}-13$ & $1.1 \mathrm{E}-13$ & $6.8 \mathrm{E}-16$ & $1.6 \mathrm{E}-12$ & $6.4 \mathrm{E}-14$ & $1.1 \mathrm{E}-12$ \\
\cline { 2 - 9 } & Medium & $1.0 \mathrm{E}-12$ & $4.5 \mathrm{E}-13$ & $1.2 \mathrm{E}-13$ & $7.0 \mathrm{E}-16$ & $2.8 \mathrm{E}-12$ & $9.1 \mathrm{E}-14$ & $1.4 \mathrm{E}-12$ \\
\cline { 2 - 9 } & High & $3.5 \mathrm{E}-13$ & $2.0 \mathrm{E}-13$ & $5.0 \mathrm{E}-14$ & $3.9 \mathrm{E}-15$ & $1.4 \mathrm{E}-13$ & $2.4 \mathrm{E}-13$ & $5.4 \mathrm{E}-13$ \\
\hline
\end{tabular}

Table S3.4 Results of the life cycle analysis of each FS. Weighting of normalized values

\begin{tabular}{|c|c|c|c|c|c|c|c|c|}
\hline \multicolumn{2}{|c|}{$\begin{array}{l}\text { Impact } \\
\text { categories }\end{array}$} & GWP & $\mathbf{A P}$ & EP & ODP & РОCP & ADPE & ADPF \\
\hline \multirow{3}{*}{ PST } & Low & $6.8 \mathrm{E}-14$ & $2.5 \mathrm{E}-14$ & $6.8 \mathrm{E}-15$ & $5.0 \mathrm{E}-16$ & $1.9 \mathrm{E}-14$ & $3.2 \mathrm{E}-14$ & $7.9 \mathrm{E}-14$ \\
\hline & Medium & $9.2 \mathrm{E}-14$ & 3.0E-14 & $1.5 \mathrm{E}-14$ & 5.7E-16 & $2.8 \mathrm{E}-14$ & $3.2 \mathrm{E}-14$ & $8.5 \mathrm{E}-14$ \\
\hline & High & $1.3 \mathrm{E}-13$ & $3.9 \mathrm{E}-14$ & $2.4 \mathrm{E}-14$ & $6.5 \mathrm{E}-16$ & $3.9 \mathrm{E}-14$ & $3.4 \mathrm{E}-14$ & $1.0 \mathrm{E}-13$ \\
\hline \multirow{3}{*}{ NS } & Low & $1.1 \mathrm{E}-13$ & $3.6 \mathrm{E}-14$ & $1.3 \mathrm{E}-14$ & 4.3E-16 & 1.9E-14 & $7.2 \mathrm{E}-15$ & $1.3 \mathrm{E}-13$ \\
\hline & Medium & $1.4 \mathrm{E}-13$ & 4.2E-14 & $2.1 \mathrm{E}-14$ & $4.9 \mathrm{E}-16$ & $2.8 \mathrm{E}-14$ & $7.8 \mathrm{E}-15$ & $1.4 \mathrm{E}-13$ \\
\hline & High & 1.7E-13 & $5.0 \mathrm{E}-14$ & $3.1 \mathrm{E}-14$ & 5.7E-16 & $3.9 \mathrm{E}-14$ & $9.2 \mathrm{E}-15$ & $1.5 \mathrm{E}-13$ \\
\hline \multirow{3}{*}{ PVC } & ow & 1.7E-13 & $5.3 \mathrm{E}-14$ & $1.4 \mathrm{E}-14$ & $5.4 \mathrm{E}-17$ & $8.5 \mathrm{E}-14$ & $3.4 \mathrm{E}-14$ & $2.8 \mathrm{E}-13$ \\
\hline & Medium & $2.2 \mathrm{E}-13$ & $6.5 \mathrm{E}-14$ & 3.0E-14 & $1.9 \mathrm{E}-16$ & 1.0E-13 & 3.6E-14 & $2.9 \mathrm{E}-13$ \\
\hline & High & $2.7 \mathrm{E}-13$ & 7.6E-14 & $4.8 \mathrm{E}-14$ & $3.4 \mathrm{E}-16$ & $1.2 \mathrm{E}-13$ & 3.7E-14 & $3.0 \mathrm{E}-13$ \\
\hline \multirow{3}{*}{ TEX } & Low & $3.8 \mathrm{E}-13$ & $9.9 \mathrm{E}-14$ & 4.7E-14 & $3.4 \mathrm{E}$ & $9.4 \mathrm{E}-1$ & $.9 \mathrm{E}-13$ & $4.0 \mathrm{E}-13$ \\
\hline & Medium & $5.1 \mathrm{E}-13$ & $1.3 \mathrm{E}-13$ & $7.4 \mathrm{E}-14$ & 5.6E-16 & 1.3E-13 & $3.0 \mathrm{E}-13$ & $4.7 \mathrm{E}-13$ \\
\hline & High & $6.4 \mathrm{E}-13$ & 1.6E-13 & $1.2 \mathrm{E}-13$ & $9.8 \mathrm{E}-16$ & $1.8 \mathrm{E}-13$ & $3.0 \mathrm{E}-13$ & $4.9 \mathrm{E}-13$ \\
\hline \multirow{3}{*}{ LAM } & Low & $1.6 \mathrm{E}-13$ & $7.2 \mathrm{E}-14$ & $2.9 \mathrm{E}-14$ & $6.9 \mathrm{E}-17$ & $9.4 \mathrm{E}-14$ & $5.5 \mathrm{E}-15$ & $2.1 \mathrm{E}-13$ \\
\hline & Medium & $2.0 \mathrm{E}-13$ & $8.2 \mathrm{E}-14$ & 4.0E-14 & 1.6E-16 & $1.1 \mathrm{E}-13$ & 7.0E-15 & $2.3 \mathrm{E}-13$ \\
\hline & High & $2.0 \mathrm{E}-13$ & 8.1E-14 & $4.0 \mathrm{E}-14$ & 1.6E-16 & 1.1E-13 & 6.7E-15 & $2.3 \mathrm{E}-13$ \\
\hline \multirow{3}{*}{ WD } & Low & $1.6 \mathrm{E}-13$ & $5.1 \mathrm{E}-14$ & $1.5 \mathrm{E}-14$ & 8.7E-17 & $2.1 \mathrm{E}-13$ & $8.5 \mathrm{E}-15$ & $1.6 \mathrm{E}-13$ \\
\hline & Medium & $1.9 \mathrm{E}-13$ & $5.8 \mathrm{E}-14$ & 1.7E-14 & $9.0 \mathrm{E}-17$ & 3.7E-13 & $1.2 \mathrm{E}-14$ & $2.1 \mathrm{E}-13$ \\
\hline & High & $3.4 \mathrm{E}-13$ & $1.1 \mathrm{E}-13$ & $3.2 E-14$ & 1.9E-16 & $5.8 \mathrm{E}-13$ & 2.0E-14 & $3.5 \mathrm{E}-13$ \\
\hline
\end{tabular}

\section{References}

ISO 14044, 2006. Environmental management -- Life cycle assessment -- Requirements and guidelines. International Organization for Standardization, Geneva.

Laurin, L., Amor, B., Bachmann, T.M., Bare, J., Koffler, C., Genest, S., Preiss, P., Pierce, J., Satterfield, B., Vigon, B., 2016. Life cycle assessment capacity roadmap (section 1): decisionmaking support using LCA. Int. J. Life Cycle Assess. 21, 443-447. https://doi.org/10.1007/s11367-016-1031-y 